\title{
EVALUATION OF RADIOLOGICAL CONDITIONS IN THE VICINITY OF HANFORD FOR 1968
}

May 1970

\section{AEC RESEARCH \& DEVELOPMENT REPORT}




\section{LEGAL NOTICE}

This report was prepared as an account of Government sponsored wark. Neither the United States, nor the Commission, nor any person acting on behalf of the Commission:

A. Makes any warranty or representation, expressed or implied, with respect to the accuracy, completeness, or usefulness of the information contained in this report, or that the use of any information, apparatus, method, or process disclosed in this report may not infringe privately owned rights; or

B. Assumes any liabilities with respect to the use of, or for damages resulting from the use of any information, apparatus, method, or process disclosed in this report.

As used in the above, "person acting on behalf of the Commission" includes any employee or contractor of the Commission, or employee of such contractor, to the extent that such employee or contractor of the Cammission, or employee of such contractar prepares, disseminates, or provides access to, any information pursuant to his employment or contract with the Commission, or his employment with such contractor.

\section{PACIFIC NORTHWEST LABORATORY}

RICHLAND, WASHINGTON

operated by

BATTELLE MEMORIAL INSTITUTE

for the

UNITED STATES ATOMIC ENERGY COMMISSION UNDER CONTRACT AT(45-1)-1830 
BNWL-1341

UC-41, Health and Safety

EVALUATION OF RADIOLOGICAL CONDITIONS

IN THE VICINITY OF HANFORD FOR 1968

By

The Environmental Evaluations Staff

W. L. Fisher, Manager

Edited by

C. B. Wilson

Radiation Protection Department

Technical Services Division

May 1970

FIRST UNRESTRICTEO

DISTRIBUTION MADE

JUL $155^{\prime} 70$

BATTELLE MEMORIAL INSTITUTE

PACIFIC NORTHWEST LABORATORIES

RICHLAND, WASHINGTON 99352 
BNWL - 1341

Printed in the United States of America Available from

Clearinghouse for Federal Scientific and Technical Information National Bureau of Standards, U.S. Department of Commerce Springfield, Virginia 22151

Price: Printed Copy $\$ 3.00 ;$ Microfiche $\$ 0.65$ 
BNWL- 1341

\section{EVALUATION OF RADIOLOGICAL CONDITIONS \\ IN THE VICINITY OF HANFORD FOR 1968 \\ Edited by C. B. Wilson}

\section{ABSTRACT}

At the Hanford project, controlled releases of a variety of low-level radioactive wastes are made to the Columbia River, to the ground, and to the atmosphere. The major source of low-level wastes released to the environment in 1968 continued to be reactor cooling water discharged to the Columbia River. Evaluation of the combined offsite effects of all radioactive waste releases during 1968 showed that concentrations of radionuclides in the environs and radiation doses received by nearby population groups were well within accepted standards. Doses were estimated for the whole body, gastrointestinal-tract, and thyroid as in previous years and, for the first time, the annual intake of bone-seeking radionuclides was also expressed in terms of dose to skeletal bone.

The population considered included the Maximum Individual, the Average Richland Resident, and the Typical Richland Resident. Population dose estimates were less than one-tenth of the appropriate standards except for the skeletal bone of the Maximum Individual (17\% of the $1500 \mathrm{mrem} /$ year standard) and for the thyroid of the infant Typical Richland Resident (11\% of the $500 \mathrm{mrem} /$ year standard). A single radionuclide, ${ }^{32} \mathrm{P}$, contributed $96 \%$ of the estimated skeletal bone dose received by the Maximum Individual with Columbia River fish the major source of intake.

On a comparable basis, these population dose estimates for 1968 would represent a decrease from those of 1967. However, because of changes in the method of computation, the percentages of standard for 1968 are not directly comparable to those reported for 1967. 
BNWL - 1341

\section{CONTENTS}

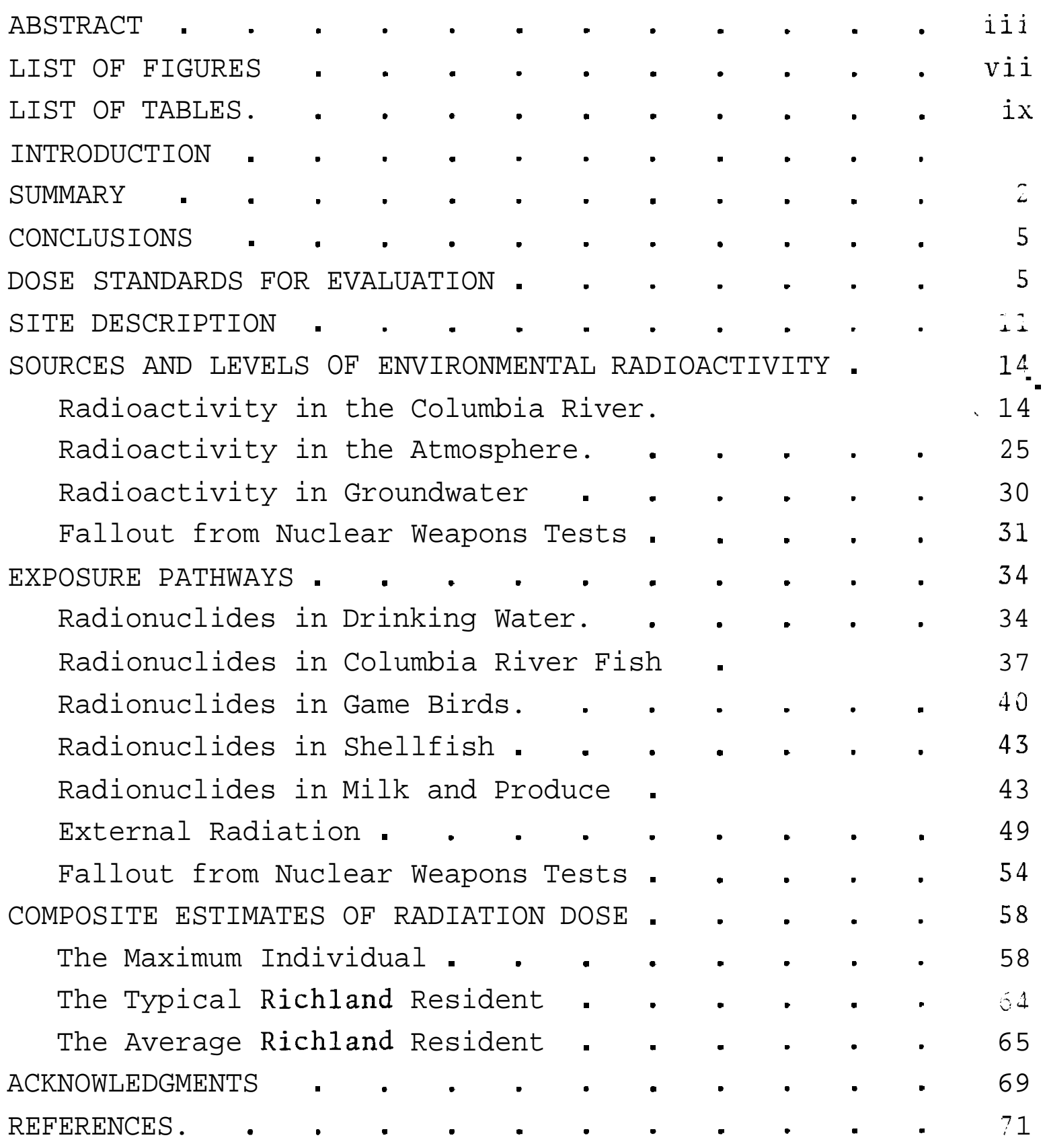


BNWL - 1341

\section{LIST OF FIGURES}

1 Geographical Relationship of Hanford to the Pacific Northwest

2 Features of Hanford Project and Vicinity 13

3 Weekly Average Flow Rate of the Columbia River at Priest Rapids and Bonneville Dams

4a $\quad{ }^{32} \mathrm{P},{ }^{51} \mathrm{Cr}$, and ${ }^{131} \mathrm{I}$ Transport Rates in the Columbia River at Richland

$4 \mathrm{~b} \quad{ }^{46} \mathrm{Sc}$ and ${ }^{65} \mathrm{Zn}$ Transport Rates in the Columbia River at Richland

$5 \quad$ Monthly Average ${ }^{32} \mathrm{p}$ Concentrations in Flesh of Whitefish Caught in the Columbia River Between Ringold and Rich1and

6 Offsite Air Sampling Locations 26

7 Monthly Average ${ }^{131}$ I Concentrations in the Air of Hanford Environs

8 Monthly Average Particulate Total Beta Concentrations in the Air of Hanford Environs

$9 \quad 3_{\mathrm{H}}$ Concentrations in Groundwater - JulyDecember, 1968

$10 \quad{ }^{106} \mathrm{Ru}$ Concentrations in Groundwater - JulyDecember, 1968

11 Relative Contribution of Various Radionuclides in Richland Drinking Water to the GI Tract Dose for 1968

12 Doses to the GI Tract from Richland and Pasco Drinking Water

$13 \quad 32 \mathrm{p}$ and ${ }^{65} \mathrm{zn}$ Concentrations in Willapa Bay Oysters

14 Monthly Average ${ }^{32} \mathrm{P}$ and ${ }^{65} \mathrm{zn}$ Concentrations in Milk from River-Irrigated Farms

15 Monthly Average ${ }^{131}$ I Concentrations in Locally Available Milk

16 Monthly Average Gamma Exposure Rates at Hanford Test Location and at Richland 
17 Monthly Average External Gamma Exposure Rates at the Columbia River Shoreline at Richland and at Sacajawea Park

18 Monthly Average ${ }^{90}$ Sr Concentrations in Locally Available Milk

19 Monthly Average Available Milk

${ }^{137}$ Cs Concentrations in Locally

20 Estimated Doses to the Maximum Individual - 1968

21 Estimated Doses to the Typical Richland Resident - 1968

22 Estimated Doses to the Average Richland Resident - 1968 


\section{LIST OF TABLES}

1 Summary of Radiation Doses in the Hanford Environs, 1968

2 Radiation Protection Standards for External and Internal Exposure

3 Dose Factors for Certain Bone-Seeking Radionuclides

4 Comparison of Percentage of $1.5 \mathrm{rem} / \mathrm{year}$ Standard for Bone for an Adult Individual Based on MPRI and Based on Current Dose-Factors

5 Relative Abundance of Reactor Effluent Radionuclides

6 Annual Average Concentrations of Several Radionuclides in Columbia River Water

7 Annual Average Transport Rates of Selected Radionuclides Past Bonneville Dam

8 Annual Average ${ }^{131_{I}}$ Concentrations in the Atmosphere

9 Average Concentrations of Several Radionuclides in Drinking Water, 1968

10 Calculated Annual Doses to Selected Organs from Routine Ingestion of Drinking Water, 1968

11 Average ${ }^{32} \mathrm{p}$ and ${ }^{65} \mathrm{Zn}$ Concentrations in Muscle of River Birds

12 Species Distribution of Local Game Birds

13 Contribution of Each Species to $100 \mathrm{~g}$ of an Average Game Bird Meal

14a 1968 Annual Radiation Doses from Individual Fallout Nuclides

14b Total Annual Radiation Doses During 1967 and 1968 from Fallout Nuclides

15. Dietary Assumptions

16 Summary of Radiation Doses in the Hanford Environs, 1968

17 Dose Estimates for Maximum Individual 1964 to 1968 
BNWL - 1341

\section{EVALUATION OF RADIOLOGICAL CONDITIONS \\ IN THE VICINITY OF HANFORD FOR 1968 \\ Edited by C. B. Wilson}

\section{INTRODUCTION}

A variety of radioactive wastes are generated by the Hanford production reactors, chemical separations plants, and laboratories. High level wastes are concentrated and retained in storage within the project boundaries. Controlled releases of low-level wastes, for which concentration and storage are not feasible, are made to the ground, to the atmosphere, and to the Columbia River. The Atomic Energy Commission regulations governing radioactive waste disposal at Hanford are described in the AEC Manual Chapter RL 0510. (1) During 1968, the plant facilities were operated for the Atomic Energy Commission by: Atlantic Richfield Hanford Company; Pacific Northwest Laboratories of Battelle Memorial Institute; DouglasUnited Nuclear, Incorporated; and ITT Federal Support Services, Incorporated.

The purpose of this report is to present an evaluation of the combined offsite effects of the radioactive waste management practices of all Hanford contractors during 1968. Analytical data on which this evaluation is based have been published as a separate report (BNWL-1341 APP). (2) The previous reports in this series were BNWL-983 and BNWL-983 APP. (3) 
BNWL- 1341

\section{SUMMARY}

Surveillance of the Hanford environs during 1968 showed that both environmental concentrations of radioactive materials and the environmental radiation doses of Hanford origin received by local residents were well within appropriate guides and standards. The environmental surveillance program for 1968 also indicated that most of the environmental radiation dose for the majority of persons living in the Hanford environs was due to natural sources and worldwide fallout rather than to Hanford operations. The major source of low-level wastes released to the environment from Hanford plants continued to be reactor cooling water discharged to the Columbia River.

An announced foreign weapons test ${ }^{(4)}$ caused increased ${ }^{131}$ I concentrations in the environment in January 1968 and higher concentrations of total beta activity associated with airborne particulates during the first half of the year. An offsite event (5) caused an abrupt temporary increase in atmospheric beta activity in December.

An unlikely, but plausible, combination of living and dietary habits that probably would result in an individual's receiving the largest radiation dose from Hanford-effluent radionuclides has been postulated ${ }^{(3)}$ as:

- Consumption of 200 meals/yr of fish caught down river from the reactors

- Spending $500 \mathrm{hr} / \mathrm{yr}$ on the riverbank to catch the above quantity of fish

- Consumption of meat, milk, fruit, and vegetables from irrigated farms in the Riverview district

- Consumption of drinking water from the Pasco system.

A person with such habits is called the Maximum Individual. During 1968, the Maximum Individual's bone dose from ingested materials (mostly $32 \mathrm{P}$ ) and from shoreline exposure was estimated 
to be $17 \%$ of the standard (1500 mrem/yr) for individual members of the population. Doses to the GI tract and whole body from such sources were estimated to be 4 and $5 \%$, respectively, of the appropriate standards.

A Typical Richland Resident has been defined in previous years, $(3,6,7)$ for the purpose of estimating doses to bone, whole body, and GI tract, as an adult consuming typical quantities (as given in the literature) of Richland drinking water derived from the Columbia River, and of milk, meat, and other foodstuffs from commercial sources. The radiation doses of Hanford origin received by such an individual come, for the most part, from Richland drinking water, with the GI tract normally receiving the largest percentage of permissible dose for the adult (5\% in 1968). For the purpose of estimating thyroid dose, a Typical Richland Resident has been defined as an infant with a 2 g thyroid. His sources of food and water are the same as those of the adult. The thyroid dose to a Typical Richland Resident (Infant) for 1968 was 55 mrem or $11 \%$ of the appropriate standard. As in 1967, this estimate includes a dose contribution from short-lived radioiodine that had not been included in previous years.

The Average Richland Resident ${ }^{(3)}$ is also defined as an adult for purposes of estimating bone, whole body, and GI tract doses and as an infant for estimating thyroid dose. However, the adult dietary habits of the Average Richland Resident have been determined from local dietary surveys and thus provide a better basis for dose-estimation than those of the Typical Richland Resident.

Radiation dose from Hanford sources received by this population group also originates, for the most part, from drinking water derived from the Columbia River. However, radionuclide concentrations are adjusted for decay and dilution in the water 
distribution system. For the adult, the GI-tract dose is normally the largest percentage of appropriate standards for the mixture of radionuclides present in drinking water. During 1968, this dose was 5\% of the standard for the general population. The thyroid dose to the infant Average Richland Resident (2 g thyroid) for 1968 was 8\% of the appropriate standard, including a contribution from short-lived radioiodines.

Estimated radiation doses to the above-defined residents resulting from the combined effects of Hanford contractor operations are summarized in Table 1 with the appropriate standards for comparison.

TABLE 1. Summary of Radiation Doses (a) in the Hanford Environs, 1968

Organ

\begin{tabular}{ccc}
$\begin{array}{c}\text { Annual Dose, } \\
\text { mrem }\end{array}$ & $\begin{array}{c}\text { Standard, } \\
\text { mrem }\end{array}$ \\
\hline
\end{tabular}

Maximum Individual

Bone

Whole Body

GI Tract

Thyroid (infant)
250

24

62

110

Typical Richland Resident

Bone

Whole Body

GI Tract

Thyroid (infant)

$\underline{\text { Average Richland Resident }}$

Bone

Whole Body

GI Tract

Thyroid (infant)

$\begin{array}{rrr}8 & 500 & 2^{(b)} \\ 3 & 170 & 2 \\ \mathbf{2 4} & 500 & 5 \\ 55 & 500 & 11\end{array}$

13

500

$3(b)$

3

25

170

2

500

5

39

500 $17^{(b)}$

5

4

7

a. Doses from fazzout and naturaz background not included.

b. In 1967, bone dose was expressed in terms of MPRI. Therefore, the 1968 estimates are not directly comparable. See the following section in this report, 'Dose Standards for Evaluation." 
BNWL - 1341

\section{CONCLUSIONS}

The results of the 1968 environmental surveillance program at Hanford again showed that the amounts of radionuclides as measured in the environs were well within accepted standards. The only estimates exceeding one-tenth of the appropriate standard were for the bone of the hypothetical Maximum Individual (17\% of the $1500 \mathrm{mrem} / \mathrm{yr}$ standard) and for the thyroid of the infant Typical Richland Resident (11\% of the $500 \mathrm{mrem} / \mathrm{yr}$ standard). Because of changes in the method of computation, these dose estimates for the environmental population are not completely comparable to 1967 levels, but on a comparable basis they would represent a decrease. Process improvements and the shutdown of plant facilities both have contributed to a decrease in environmental doses from 1965 to 1968.

\section{DOSE STANDARDS FOR EVALUATION}

Radiation protection practices at Hanford, including radioactive waste disposal, are governed by the AEC Manual. (1) Chapters 0524 and RL 0524 provide the following standards for permissible radiation exposures in uncontrolled areas. The section of RL 0524 Appendix to which this evaluation is addressed is shown in Table 2.

It is not possible to determine precisely the radiation dose received by every individual because of variations in the kinds, quantities, and sources of food and water consumed: variations in physiological characteristics with age and body size; and many variations in personal living habits. These inherent variations between individuals require a somewhat subjective approach when estimating probable radiation doses in relation to various established limits. The Federal Radiation Council (FRC) and the AEC have provided two sets of criteria by which doses from environmental sources may be judged. One is for the greatest dose received by critical individuals and the other for the average dose received by the general population. 
"TABLE 2. Radiation Protection Standards for External and Internal Exposure( $(8)$

Annual Dose or Dose Commitment, rem

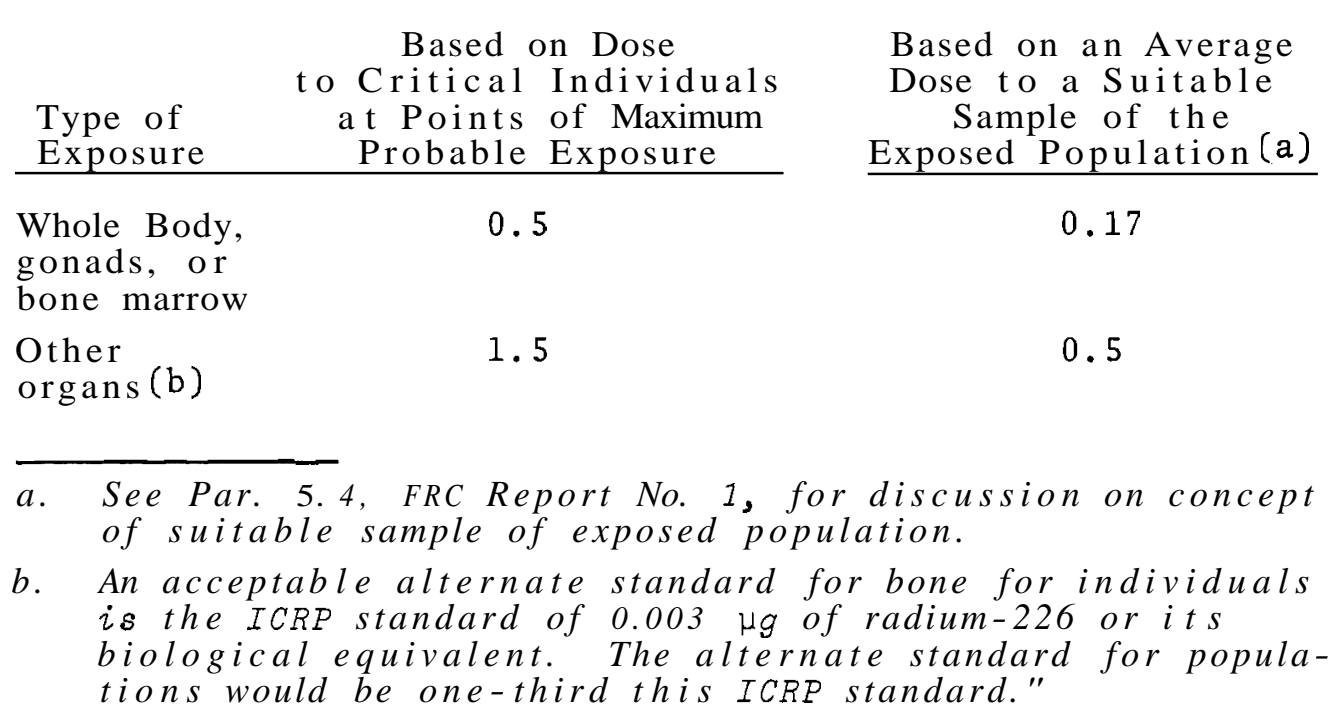

For the Hanford environs, doses from the various exposure pathways described in the following sections have been combined for comparisons with guides for both the individual and the general population. As in previous years, a hypothetical Maximum Individual has been assigned pessimistic dietary and other habits in order to estimate doses comparable to the standards for critical individuals in the preceding table. For thyroid dose considerations, the Maximum Individual has been assumed to be an infant.

Individuals with a somewhat larger dose to a specific organ than has been estimated for the Maximum Individual may be indicated by additional information on different age groups or persons with unique diet habits or physiological behavior. The likelihood that any such person could have received a dose approaching the standards is considered quite remote. For example, certain Richland teenagers may have received greater whole body doses in 1968 than the Maximum Individual (see page 53). However, these doses were well within accepted standards. For 
the general population, a dose has been estimated in previous years for what was called the Typical Richland Resident. In each case, the best available information on dietary patterns was used. Such a dose estimation was included for 1968.

In.1967, sufficient diet information became available for the first time to make a reasonable estimate of average doses to Richland adults. In our judgment, this provides a more suitable comparison against dose standards applicable to the general population as given in AEC Manual Chapter 0524 (8) than the assumptions previously used for a Typical Richland Resident. For continuity, we have presented both types of estimates in this annual report.

Radiation doses to the population near the Hanford project have been estimated in some detail since 1957.(3, 9-18) In recent years (1960-1967), the dose calculations for most critical organs were expressed in terms of dose-equivalent rates (i.e., rem/yr) rather than in terms of a Maximum Permissible Rate of Intake (MPRI). The MPRI was taken as the Maximum Permissible Concentration (MPC) in water for a given radionuclide as recommended by the International Commission on Radiological Protection (ICRP) for persons in the neighborhood of controlled areas, $(19,20,21)$ multiplied by the rate of water intake as defined for the standard man. This amounts to onetenth of the MPC for continuous occupational exposure multiplied by intake rates of 2.2 1iters/day or 800 1iters/yr (for annual estimates).

Only the dose to the bone was still phrased in the MPRI terminology because the significance of bone seekers, such as ${ }^{32} \mathrm{P}$ and ${ }^{90} \mathrm{Sr}$ has required special consideration and treatment. The rate of intake of ${ }^{32} \mathrm{P}$ has not been specifically studied by the FRC (Federal Radiation Council) $(22,23,24)$ in relation to a dose-equivalent for the bone or bone marrow. 
In view of the AEC instruction that ICRP-NCRP (National Council on Radiation Protection and Measurements) dosimetry methods $(23,25)$ be used where the FRC does not provide direct guidance, and in view of a more conservative rate of intake for ${ }^{32} \mathrm{P}$ implied by the ICRP-NCRP recommendations than by use of a computational scheme for ${ }^{32} \mathrm{P}$ similar to that used by the FRC for ${ }^{90} \mathrm{Sr}$, we continued to use the ICRP values as a reference base. In the case of ${ }^{32} \mathrm{P}$, the MPRI for bone for individuals in the neighborhood of controlled areas (derived from ICRP values) is $16.1 \mu \mathrm{Ci} / \mathrm{yr}$. For ${ }^{65} \mathrm{Zn}$, the MPRI for bone is $803 \mu \mathrm{Ci} / \mathrm{yr}$.

It is currently recognized that although some problems still exist in the accurate translation of the intake rate of a radionuclide into dose-equivalent for bone, these problems are not of a greater order of magnitude than those that exist for many other organs. Thus in 1968, MPRI terminology was abandoned and the doses to the skeleton from ${ }^{32} \mathrm{P}$ and ${ }^{65} \mathrm{Zn}$ (of Hanford origin) and ${ }^{90} \mathrm{Sr}$ (from fallout) were expressed in dose-equivalents derived from their annual intake rates by applying the dose factors given in Table 3. (26)

\section{TABLE 3. Dose Factors for Certain Bone-Seeking Radionuclides} $\mathrm{mrem} / \mu \mathrm{Ci}$ Intake(a)

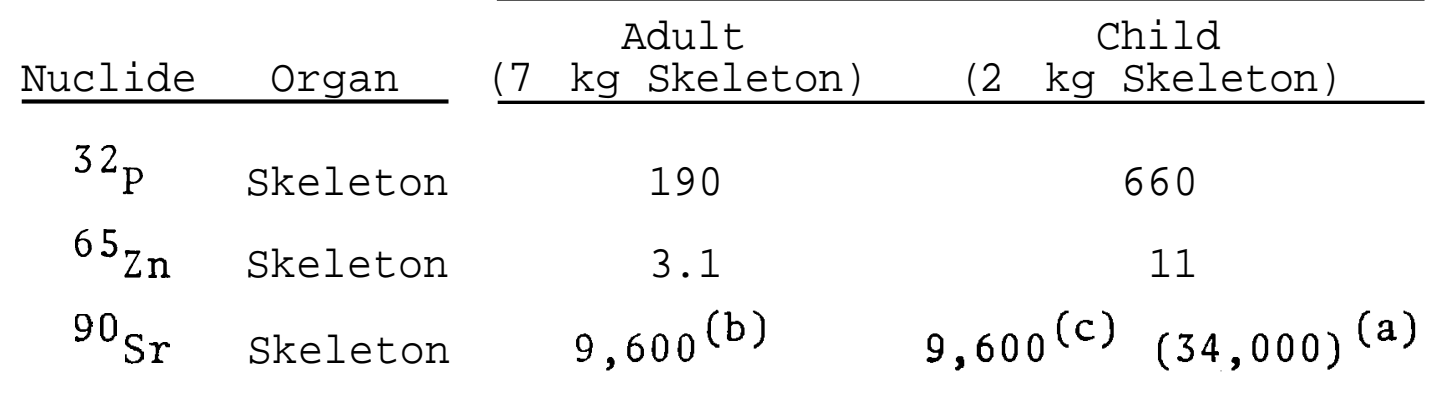

a. Based on ICRP metabolic parameters being invariant with age unless otherwise noted.

b. Approximately the same values can be derived from either the ICRP data at equilibrium or from specific activity.

c. Based on specific activity in the skezeton being 0.25 times that of the diet at alz ages. 
After careful consideration, these factors for conversion of radionuclide intake to bone dose ${ }^{(26)}$ have been accepted for use at Hanford, pending further refinement through experimental evidence. The greatest needs are for experimental determination of the bone burden which will be maintained, at equilibrium, from a specific intake rate of ${ }^{32} \mathrm{P}$ and the distribution of this radionuclide throughout the skeleton. Large animal studies defining the variation of these two items with age are also needed.

Comparison with dose standards for those estimates based on MPRI and those based on the current dose-factors are shown in Table 4.

TABLE 4. Comparison of Percentage of 1.5 rem/year Standard for Bone for an Adult Individual Based on MPRI and Based on Current Dose-Factors

\begin{tabular}{|c|c|c|c|c|}
\hline \multirow[b]{2}{*}{ Radionuclide } & \multirow{2}{*}{$\begin{array}{l}\text { Intake, } \\
\mu \mathrm{Ci} / \mathrm{yr}\end{array}$} & \multirow[b]{2}{*}{ MPRI, \% } & \multicolumn{2}{|c|}{$\begin{array}{c}\text { Dose to } \\
\text { Skeletal Bone }\end{array}$} \\
\hline & & & rem & $\%$ Standard \\
\hline${ }^{32} \mathrm{P}$ & 16.1 & 100 & 3.06 & 204 \\
\hline${ }^{65} \mathrm{Zn}$ & 803 & 100 & 2.49 & 166 \\
\hline
\end{tabular}

Thus, the \% MPRI reported in previous years multiplied by two corresponds very nearly to the appropriate percentage of standard for the skeletal bone from ingested radionuclides where ${ }^{32} \mathrm{P}$ is the main contributor to the total \% MPRI. In past years when dose was expressed as \% MPRI, no contribution of external radiation to the bone dose was included. However, in 1968, the estimated dose to the skeletal bone (expressed in mrem) includes an estimated contribution from external sources of radiation of Hanford origin. 
As in the past, contributions from sources external to the body are included in the estimated doses for the GI tract and whole body. The thyroid dose estimate is for an infant who is assumed to have no exposure to external radiation of Hanford origin.

It should be noted that the total exposure to a critical organ consists of irradiation from radionuclides deposited both within that organ and elsewhere in the body, and from irradiation from sources external to the body. However, for purposes of this analysis, the estimated dose to a critical organ from internal emitters includes only contributions from radionuclides deposited within that organ.

For thyroid dose calculations, the Federal Radiation Council has given specific guidance ${ }^{(23)}$ for permissible daily ${ }^{131}$ I intake for infants, assuming a thyroid size of $2 \mathrm{~g}$. We have used this guidance, both for the translation of radioiodine intake to dose and for the selection of appropriate groups for dose evaluation.

For whole-body and GI tract dose calculations, we have used ICRP values ${ }^{(20)}$ for the several physiological parameters involved in translating intake to dose. Therefore, in 1968 all estimated organ doses (including those for bone) were calculated in dose-equivalent terms, and compared against the appropriate standards as defined in the AEC Manual. (8)

The radiological unit used throughout most of this report is the rem (dose-equivalent). When the nuclides of interest at Hanford are considered with the organs (other than skeletal bone) for which radiation doses (in rads) are calculated, the units rad and rem are numerically equal.

The term "analytical limit" is defined as the concentration at which the laboratory can measure a radionuclide with an accuracy (b as-precision composite) of $\pm 100 \%$ at the $90 \%$ 
confidence level. The detection limit for a specific radionuclide varies with sample type, sample size, counting time, and amounts of interfering radionuclides present. The "analytical limits" given represent upper bounds to these fluctuating detection limits.

\section{SITE DESCRIPTION}

The Hanford site is in a semiarid region of southeastern Washington State (Figure 1) where the average rainfall is about 16 am (6 in.). This section of the state has a sparse covering of natural vegetation primarily suited for grazing, although large areas near the site have gradually been put under irrigation during the past few years. The plant site (Figure 2) covers an area of about $1300 \mathrm{~km}^{2}\left(500 \mathrm{mi}^{2}\right)$. The Columbia River flows through the northern edge of the project and forms part of the eastern boundary. As indicated by the wind roses shown in Figure 2, prevailing winds near the plant production sites are from the northwest, with strong drainage and cross winds causing distorted flow patterns. The meteorology of the region is typical of desert areas with frequent strong inversions occurring at night and breaking during the day to provide unstable and turbulent conditions.

The populated area of primary interest is the Tri-Cities area (Richland, Pasco, and Kennewick) situated on the Columbia River directly downstream from the plant. Smaller communities in the vicinity are Benton City, West Richland, Mesa, and Othello. The population of the communities near the plant, together with the surrounding agricultural area, is about 95,000 . 


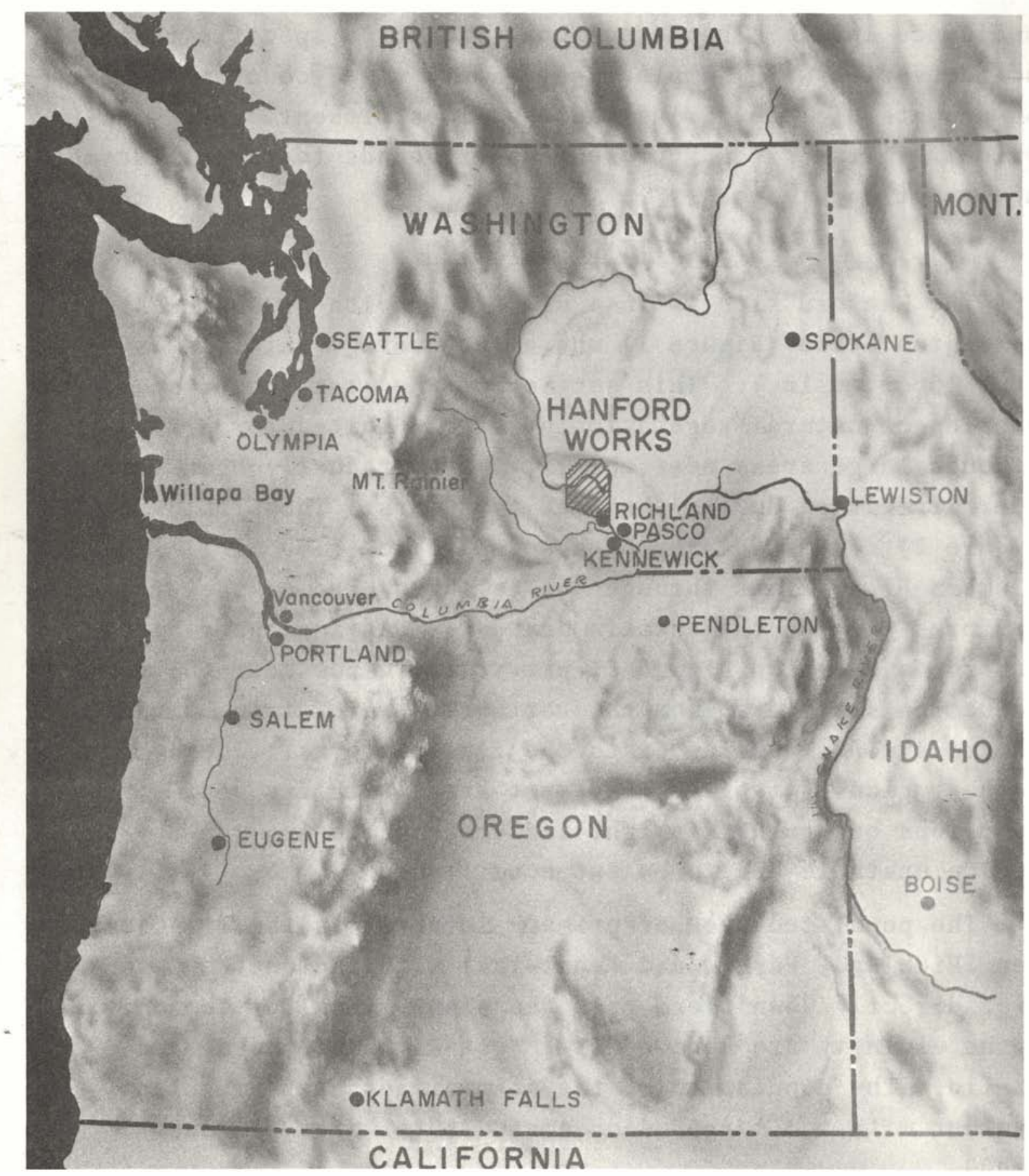

FIGURE 1. Geographical Relationship of Hanford to the Pacific Northwest 


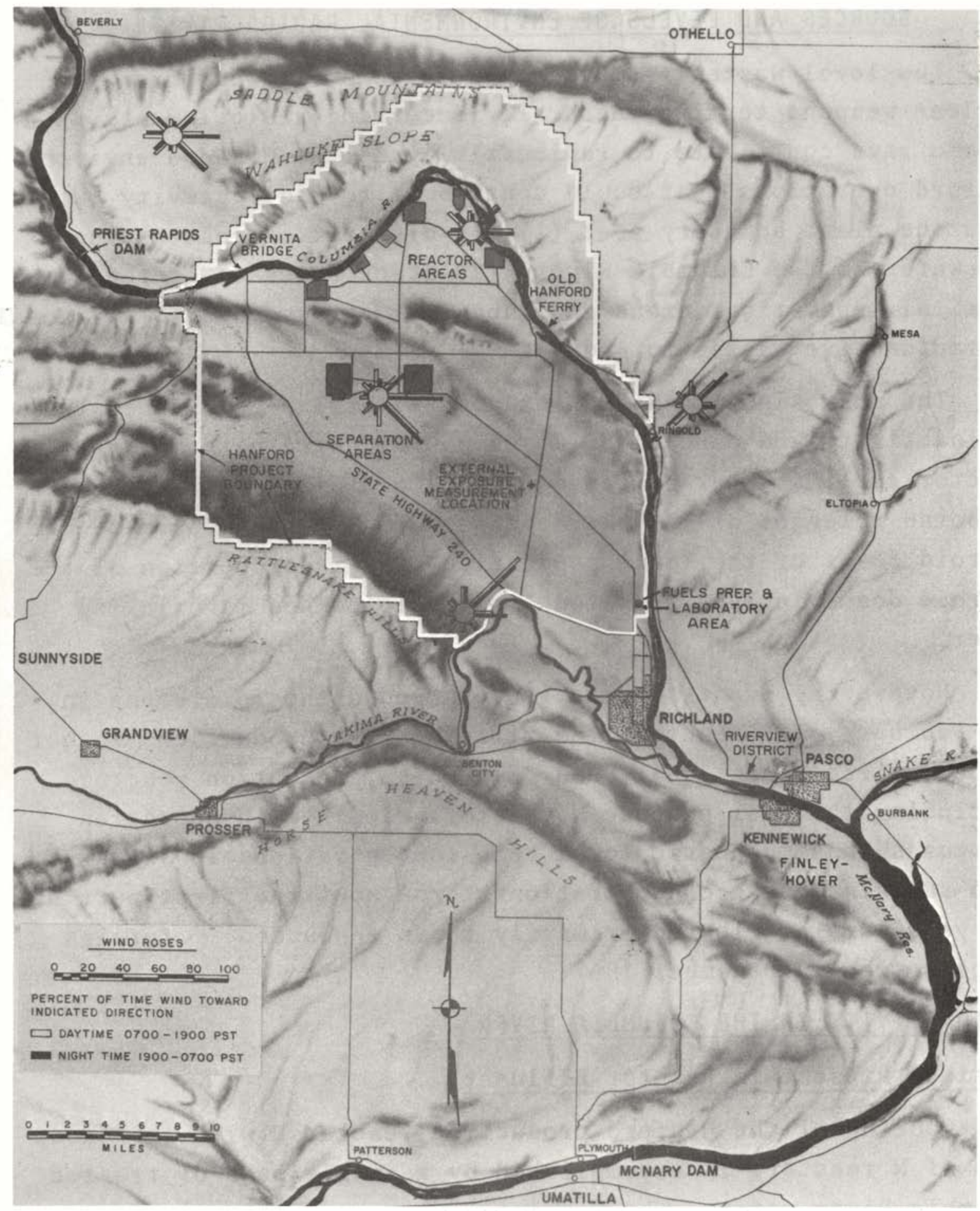

Neg 0661379-1

FIGURE 2. F'eatures of Hanford Project and the Vicinity 
BNWL-1341

\section{SOURCES AND LEVELS OF ENVIRONMENTAL RADIOACTIVITY}

Low-level wastes from plant operations, fallout from nuclear weapons testing, naturally occurring radioelements, and cosmic rays contribute to radioactivity in the Hanford environs. Hanford operations that could contribute to radioactivity outside the plant boundary are: (1) the disposal of reactor cooling water to the Columbia River, (2) stack releases at the chemical separations areas and laboratory areas, and (3) disposal of radioactive wastes to ground.

The most significant Hanford contributions to off-plant radioactivity and population doses usually originate with reactor cooling water released to the Columbia River. Although airborne releases of ${ }^{131}$ I have contributed in past years to the thyroid doses of the local population, the major portion of the thyroid doses in 1968 resulted from radioiodines in drinking water.

Noteworthy events during 1968 included the retirement in mid-February of B Reactor, the fifth Hanford production reactor to be retired since 1964. Four plutonium production reactors (including the dual-purpose $\mathrm{N}$ reactor) remained in operation. Increases in atmospheric total beta concentrations in January with sustained high concentrations throughout the first part of the year were attributed primarily to an announced ${ }^{(4)}$ foreign weapons test in December 1967.

RADIOACTIVITY IN THE COLUMBIA RIVER

Nuclides Present in Reactor Effluent

Cooling of the Hanford production reactors (with the exception of $N$ reactor) i s accomplished bya-single-pass- of treated Columbia River water. The $\mathrm{N}$ reactor uses recirculating demineralized water as a primary coolant, and all waste water containing significant amounts of radioactive material is discharged to'aground disposal site near the river. Although some of 
these radionuclides eventually enter the river, the total quantity of radioactivity entering the Columbia River from $N$ reactor is a negligibly small fraction of that released from the older reactors.

At the older reactors, some elements present in the cooling water are activated during the single pass through the reactors. In addition, radioactive materials formed on the surfaces of fuel elements and process tubes are eventually carried away by the cooling water to the river. Table 5 shows the relative abundance of the radionuclides found in the cooling water of the older production reactors, adjusted to $4 \mathrm{hr}$ after leaving the reactor.

Many of the radionuclides formed in reactor cooling water are short-lived and disappear quickly due to radioactive decay. In addition, sedimentation and uptake by aquatic organisms remove some fraction of most radionuclides from the river water. Relatively small amounts of fission products are present in the river because of the fissioning of natural uranium present in the river water, because of occasional ruptures of the fuel element jackets, and because of fallout from nuclear weapons testing,

Some radionuclides also enter the river from wastes disposed to ground, but their contribution to the total radioactivity is extremely small. (See Radioactivity in Groundwater, page 30).

River Flow Rates

The seasonal fluctuations in flow rate of the Columbia River affect radionuclide concentrations by varying the quantity of water available for dilution of reactor effluent released to the river. In addition, the seasonal scouring of sediments deposited in reservoirs behind each dam causes seasonal fluctuations in transport rates of those longer-lived 
TABLE 5. Relative Abundance of Reactor Effluent Radionuclides(a)

\begin{tabular}{|c|c|c|c|c|}
\hline $\begin{array}{c}\text { Major, } \\
90 \% \\
\end{array}$ & $\begin{array}{c}\text { Minor, } \\
9 \%\end{array}$ & \multicolumn{3}{|c|}{ Trace, $1 \%$} \\
\hline${ }^{24} \mathrm{Na}$ & ${ }^{32} \mathrm{P}$ & $3_{\mathrm{H}}$ & $91_{Y}{ }^{(b)}$ & $143 \mathrm{Ce}{ }^{(b)}$ \\
\hline${ }^{31}{ }_{\mathrm{Si}}$ & ${ }^{46} \mathrm{Sc}$ & ${ }^{14} \mathrm{C}$ & $93_{Y}{ }^{(b)}$ & $144 \mathrm{Ce}^{(\mathrm{b})}$ \\
\hline${ }^{51} \mathrm{Cr}$ & $69 \mathrm{~m}_{\mathrm{Zn}}$ & $35_{S}$ & $95_{\mathrm{Nb}}$ & $142_{\mathrm{Pr}}^{(\mathrm{b})}$ \\
\hline $56_{\mathrm{Mn}}$ & $72_{\mathrm{Ga}}$ & ${ }^{45} \mathrm{Ca}$ & ${ }^{99}{ }_{\mathrm{Mo}}$ & $143_{\operatorname{Pr}}{ }^{(b)}$ \\
\hline \multirow[t]{13}{*}{${ }^{64} \mathrm{Cu}$} & ${ }^{76} \mathrm{As}$ & $54_{\mathrm{Mn}}$ & ${ }^{103} \mathrm{Ru}$ & $147 \mathrm{Nd}^{(\mathrm{b})}$ \\
\hline & ${ }^{92} \mathrm{Sr}$ & ${ }^{59} \mathrm{Fe}$ & ${ }^{106}{ }_{\mathrm{Ru}}$ & $147_{\mathrm{Pm}}^{(\mathrm{b})}$ \\
\hline & $122 \mathrm{Sb}$ & ${ }^{60} \mathrm{Co}$ & $124_{\mathrm{Sb}}$ & $149_{\mathrm{Pm}}^{(\mathrm{b})}$ \\
\hline & $132_{\mathrm{I}}$ & $65_{\mathrm{Ni}}$ & ${ }^{131} \mathrm{I}$ & $151_{\mathrm{Pm}}(\mathrm{b})$ \\
\hline & $140_{\mathrm{La}}^{(\mathrm{b})}$ & ${ }^{65} \mathrm{Zn}$ & ${ }^{133} \mathrm{I}$ & $152_{\mathrm{Eu}}^{(\mathrm{b})}$ \\
\hline & $152 \mathrm{~m}_{\mathrm{Eu}}(\mathrm{b})$ & $87 m_{S r}$ & $135_{I}$ & ${ }^{156_{\mathrm{Eu}}}{ }^{(\mathrm{b})}$ \\
\hline & $153_{\mathrm{Sm}}^{(b)}$ & ${ }^{89} \mathrm{Sr}$ & ${ }^{136} \mathrm{Cs}$ & $153_{\mathrm{Gd}}(\mathrm{b})$ \\
\hline & $165_{\text {Dy }}{ }^{(b)}$ & ${ }^{90} \mathrm{Sr}$ & ${ }^{137} \mathrm{Cs}$ & $159_{\mathrm{Gd}}(\mathrm{b})$ \\
\hline & ${ }^{239} \mathrm{~Np}$ & ${ }^{91} \mathrm{Sr}$ & $140_{\mathrm{Ba}}$ & $160_{\mathrm{Tb}}^{(\mathrm{b})}$ \\
\hline & & $90{ }_{Y}{ }^{(b)}$ & ${ }^{141} \mathrm{Ce}{ }^{(b)}$ & $161_{\mathrm{Tb}}(\mathrm{b})$ \\
\hline & & & & $166_{\mathrm{Ho}}{ }^{(b)}$ \\
\hline & & & & $169 \operatorname{Er}^{(b)}$ \\
\hline & & & & $171_{\mathrm{Er}}{ }^{(\mathrm{b})}$ \\
\hline
\end{tabular}

a. Trace nuclide composition based on analyses, 1964 and 1968.

b. These radionuclides as a group are denoted hereafter as $R E+Y$ (Rare Earths + Yttrium). 
nuclides associated with the sediments. This is notably true for ${ }^{46} \mathrm{Sc}$ and ${ }^{65} \mathrm{Zn}$. Also affected by the flow rate is the time required for a specific volume of water to move from one location to another which in turn affects the amount of decay of the shorter-lived nuclides.

Figure 3 shows the weekly average flow rates of the Columbia River at Priest Rapids and Bonneville Dams determined from daily average flow rates published by the U.S. Geological Survey. (27) For 1968, the average river flow rate at Priest Rapids was $3380 \mathrm{~m}^{3} / \mathrm{sec}\left(120,000 \mathrm{ft}^{3} / \mathrm{sec}\right)$ which was below the 1948-1962 annual average of $3770 \mathrm{~m}^{3} / \mathrm{sec}\left(133,000 \mathrm{ft}^{3} / \mathrm{sec}.\right)$

$\underline{\text { River Concentrations }}$

During 1968, samples of river water were collected above the production reactor areas at Priest Rapids Dam and below the areas at the Richland water plant intake, McNary Dam, and Bonneville Dam. Where possible, cumulative sampling equipment was used to provide a more representative sample than periodic "grab" samples. This cumulative sampling technique, however, prevents calculation of the concentrations of radionuclides with very short half-lives; these were measured in monthly "grab" samples. Detailed measurements are reported in the Appendices. (2)

Table 6 shows the annual average radionuclide concentrations in river water at Richland and at Bonneville Dam for 1965-1968. The data for 1966 include the effects of reactor outages during the July-August strike. Comparison of 1968 with 1967 concentrations indicates a general reduction for most radionuclides. Part of the apparent reduction in ${ }^{32} \mathrm{P}$ at Richland is due to a change from "grab" to cumulative sampling. For example, the average of the cumulative samples during 1967 was $130 \mathrm{pCi} /$ iter compared to $190 \mathrm{pCi} / 1 \mathrm{iter}$ for "grab" samples of ${ }^{32} \mathrm{P}$. In 1968, concentrations of the 


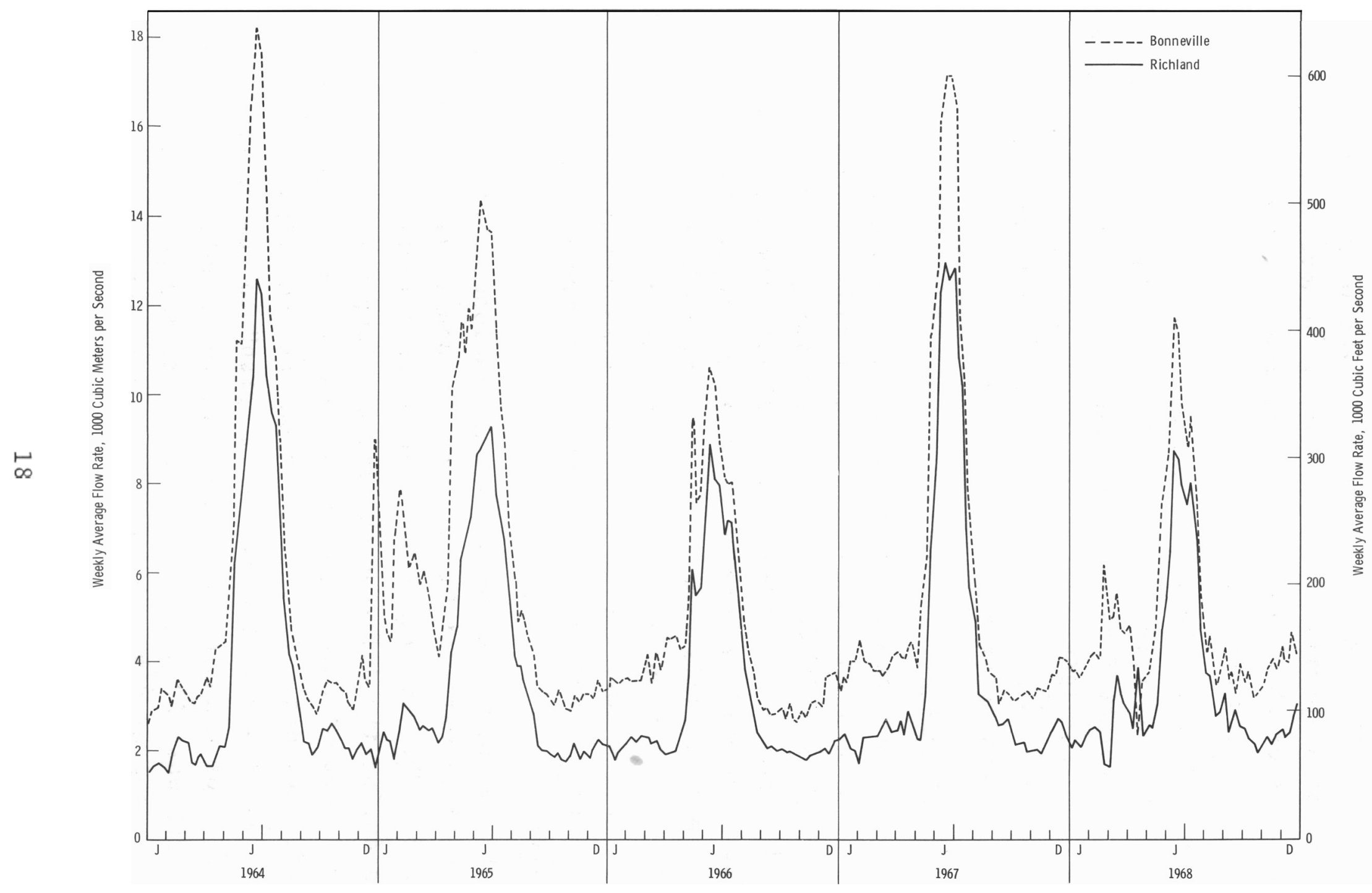

FIGURE 3. Weekly Average Flow Rate of the Columbia River at Priest Rapids and Bonneville Dams 
TABLE 6. Annual Average Concentrations of Several Radionuclides in Columbia River Water (pCi/liter)

\begin{tabular}{|c|c|c|c|c|c|c|c|c|}
\hline \multirow[b]{2}{*}{ Radionuclide } & \multicolumn{2}{|c|}{$1968^{(c)}$} & \multicolumn{2}{|c|}{1967} & \multicolumn{2}{|c|}{1966} & \multicolumn{2}{|c|}{1965} \\
\hline & Richland & $\begin{array}{c}\text { Bonneville } \\
\text { Dam }\end{array}$ & Rich1and & $\begin{array}{l}\text { Bonneville } \\
\text { Dam }\end{array}$ & Richland & $\begin{array}{l}\text { Bonneville } \\
\text { Dam }\end{array}$ & Richland & $\begin{array}{l}\text { Bonneville } \\
\text { Dam }\end{array}$ \\
\hline$R E+Y^{(a)}$ & 290 & $\ldots$ (b) & 390 & - & 270 & -- & 730 & -- \\
\hline $3_{H}^{(c)}$ & 1700 & -- & 1500 & - & - & - - & - & -- \\
\hline${ }^{24} \mathrm{Na}$ & 2200 & - & 2600 & -- & 2600 & -- & 3100 & -- \\
\hline${ }^{46} \mathrm{Sc}$ & 100 & 20 & 60 & 18 & 30 & - & - & \\
\hline${ }^{51} \mathrm{Cr}$ & 1500 & 530 & 3200 & 1400 & 3600 & 1300 & 7000 & 1700 \\
\hline${ }^{56} \mathrm{Mn}$ & 250 & -- & 520 & -- & 290 & -- & 390 & -- \\
\hline${ }^{64} \mathrm{Cu}$ & 1200 & -- & 2000 & - & 1400 & -- & 2500 & - \\
\hline${ }^{90} \mathrm{Sr}$ & $<0 . \&$ & -- & 1 & - - & 1 & - - & 1 & -- \\
\hline $95_{\mathrm{Zr}-\mathrm{Nb}}$ & $<6.3$ & -- & -- & $<5.0$ & -- & -- & - & - \\
\hline${ }^{99} \mathrm{Tc}$ & $<11$ & - & $<5.0$ & -- & -- & - & -- & -- \\
\hline${ }^{106} \mathrm{Ru}$ & $<5.0$ & - & -- & $<5.0$ & -- & - & -- & - \\
\hline $122 \mathrm{Sb}$ & $1\ulcorner 0$ & -- & 150 & -- & -- & -- & -- & -- \\
\hline${ }^{131_{I}}$ & 7.4 & $<3.2$ & 8 & 3 & 18 & 3 & 10 & 3 \\
\hline${ }^{239} \mathrm{~Np}$ & 1000 & -- & 1100 & - & 770 & -- & 1600 & - \\
\hline Total Alpha & $<1.3^{(d)}$ & -- & $<1.2$ & - - & $<1.3$ & - & $<1.1$ & -- \\
\hline
\end{tabular}

a. See Table 5 for definition.

b. The (--) indicates insufficient data to provide a meaningful annual average.

c. During 1968, results for ${ }^{3} \mathrm{H}, 32_{\mathrm{P}},{ }^{46}{ }_{\mathrm{Sc}},{ }^{51} \mathrm{Cr},{ }^{65} \mathrm{Zn},{ }^{95} \mathrm{Zr}-\mathrm{Nb}$, ${ }^{90} \mathrm{Sr}$, and ${ }^{131} \mathrm{I}$ were based on cumulative samples.

d. Based on grab samples (January-June) and on cumulative samples (July-December). 
BNWL -1341

short-lived radionuclides were expected to be lower than in previous years because fewer production reactors remained in operation. Moreover, the operating reactors are farther upstream than the retired reactors (except "B" reactor). As in past years, total alpha concentrations measured in river water at Richland were near the analytical limit (A.L. $1 \mathrm{pCi} / 1$ iter) and were not significantly different from those measured in samples collected upstream from the Hanford project.

Sampling traverses across the Columbia River at Richland have indicated a slightly nonuniform distribution of the longerlived radionuclides at this cross section. Entries of the Yakima River just below Richland and of the Snake River just below Pasco influence the distribution of radionuclides in the Columbia below these two points. The magnitude of the influence varies with seasonal changes in the flow rate of the tributaries.

Bonneville Dam, approximately $490 \mathrm{~km}$ (240 miles) below the Hanford reactors, is the farthest downstream location where river water is routinely sampled as part of the Hanford environmental surveillance program. Measurements at this location provide an upper limit to the annual transport of specific nuclides into the Pacific Ocean (Table 7).

TABLE 7. Annual Average Transport Rates of Selected Radionuclides Past Bonneville Dam (Ci/day)

\begin{tabular}{|c|c|c|c|c|c|}
\hline$\underline{\text { Radionuclides }}$ & $\underline{1968}$ & $\underline{1967}$ & 1966 & $\underline{1965}$ & $\underline{1964}$ \\
\hline${ }^{32} \mathrm{p}$ & 6.2 & 12 & 9 & 11 & 12 \\
\hline${ }^{46} \mathrm{Sc}$ & 7.5 & 10 & $\ldots(a)$ & -- & $\cdots$ \\
\hline${ }^{51} \mathrm{Cr}$ & 200 & 610 & 430 & 800 & 860 \\
\hline $65_{\mathrm{Zn}}$ & $<13$ & 40 & 21 & 49 & 44 \\
\hline
\end{tabular}

a. The (--) indicates no routine analysis was made. 
BNWL- 1341

Transport Rates

Figures $4 \mathrm{a}$ and $4 \mathrm{~b}$ show the river transport rates of several radionuclides past Richland. Table 6 shows the annual average transport rates of selected radionuclides past Bonneville Dam. More detailed measurements are presented in the Appendices. (2) Transport rates of 84 -day ${ }^{46} \mathrm{Sc}$ are now shown in Figure 4 and Table 6 because concentrations of this particular radionuclide increased to detectable values in 1967. The transport rates at Richland in 1968 for the five radionuclides shown were all lower than the 1967 values, primarily due to changes in reactor operation and the retirement of the "B" reactor.

Trend Indicator - Whitefish

The Columbia River is popular for sports fishing both above and below the Hanford reservation. Fish feeding downstream from the reactors acquire some reactor-effluent radionuclides through food chains with ${ }^{32} \mathrm{P}$ being the most significant in regard to population doses. Changes in river concentrations and temperatures may induce changes in concentrations in biological media. However, the ultimate uptake of radionuclides depends on complex environmental interrelationships. Whitefish are the sports fish that usually contain the greatest concentration of radioactive materials. Furthermore, they can be caught during winter months when other sports fish are difficult to sample. Therefore, ${ }^{32} \mathrm{P}$ data accumulated from whitefish sampling near the plant boundary are useful as a trend indicator of concentrations in biological media even though whitefish are not the most significant source of radionuclides for the local population.

Concentrations of ${ }^{32} \mathrm{P}$ in whitefish during 1968 tended to follow the same seasonal trends observed in past years (Figure 5). The average concentrations of $32 \mathrm{P}$ in whitefish sampled downstream 


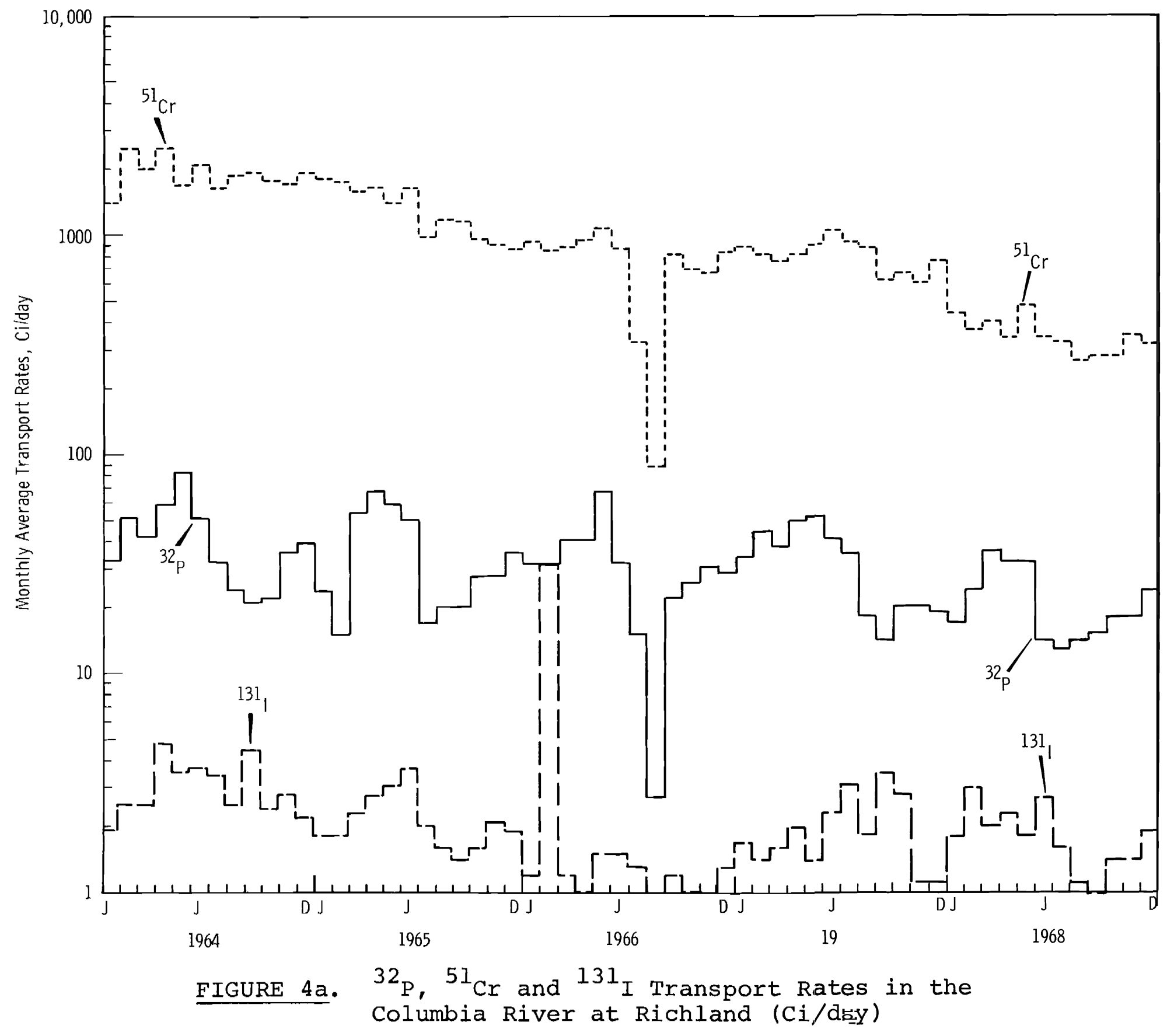

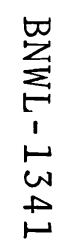




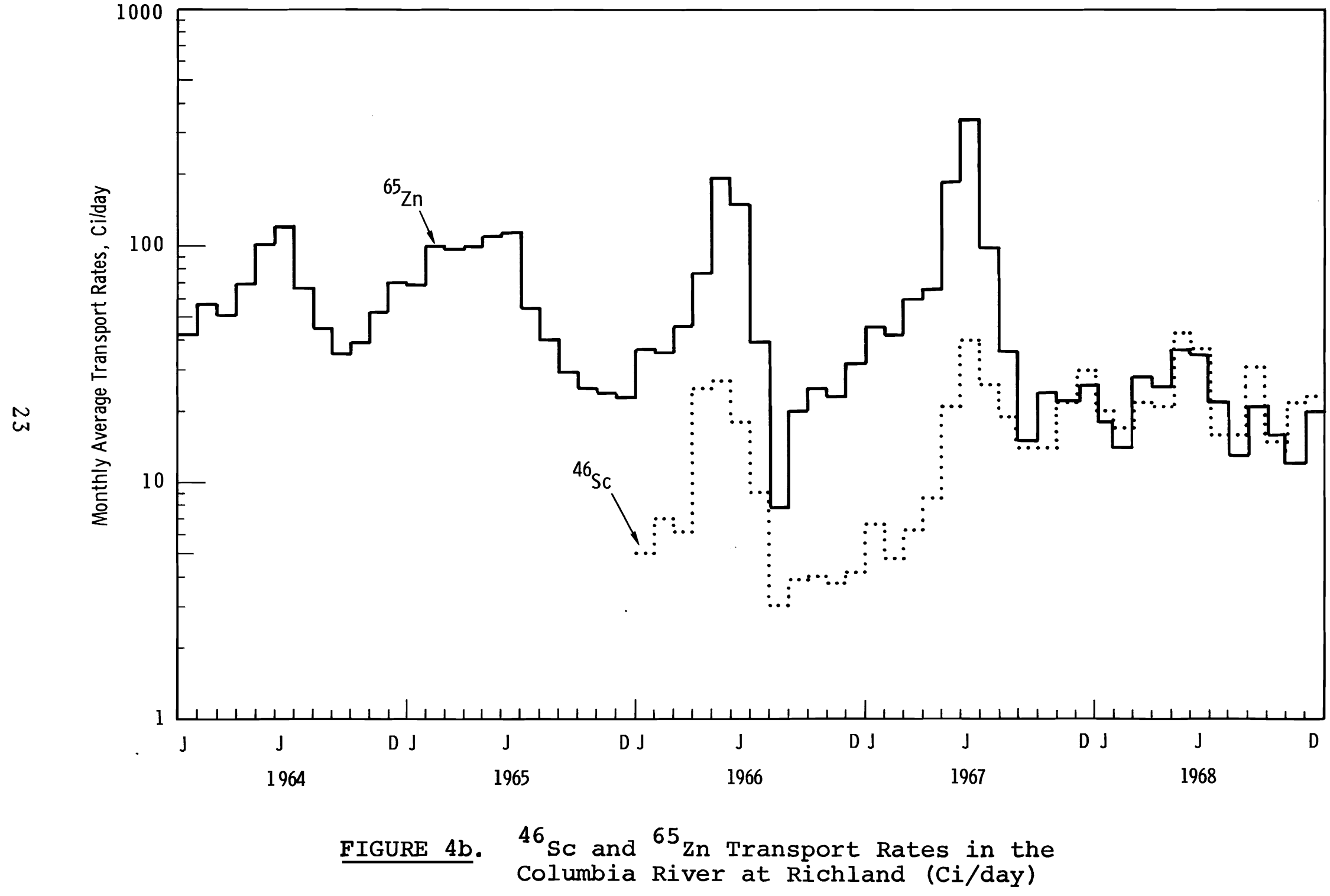




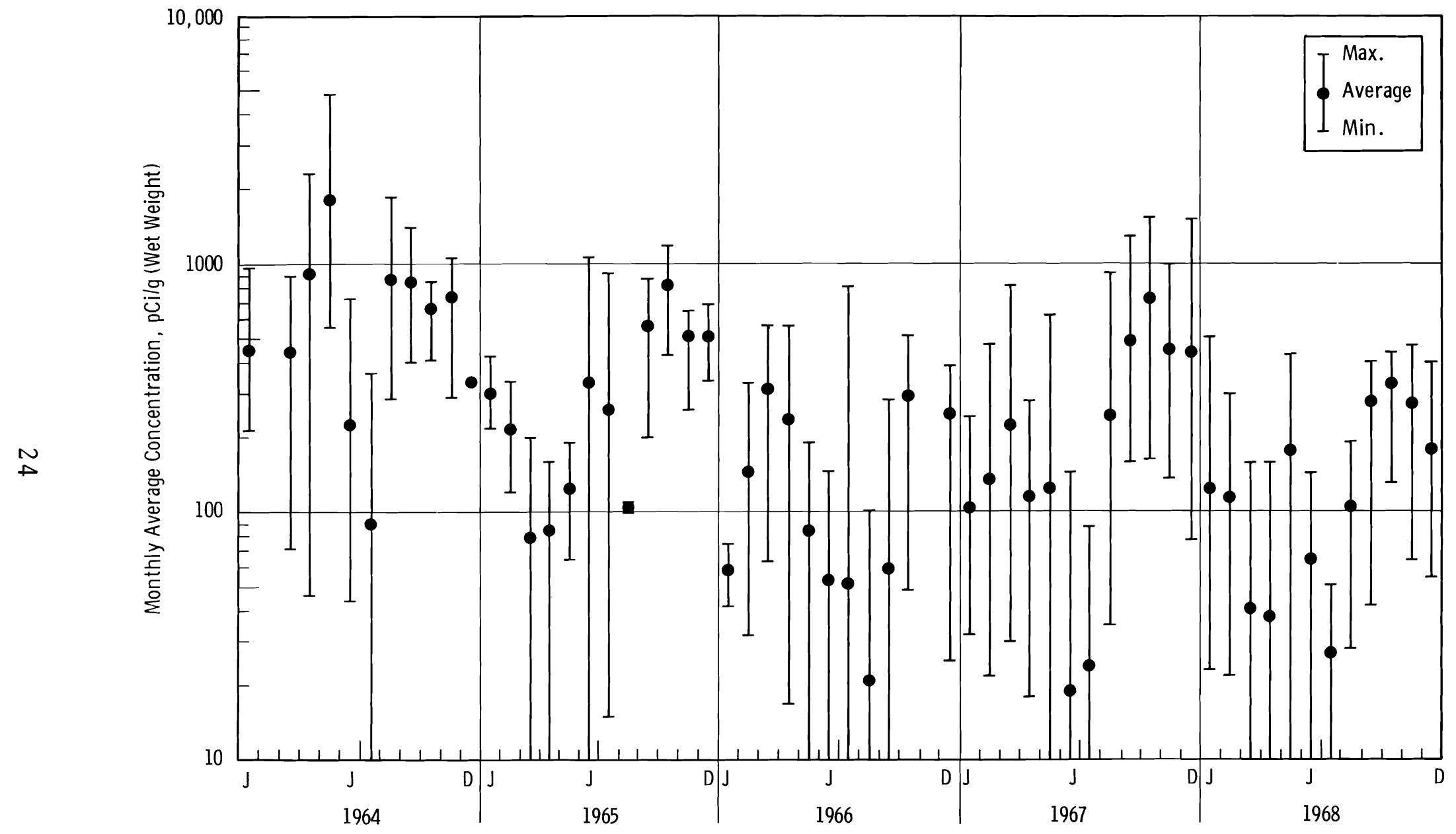

FIGURE 5. Monthly Average $32 \mathrm{P}$ Concentrations in Flesh of Whitefish Caught in the Columbia River Between Ringold and Richland (pCi/g, Wet Weight) 
BNWL- 1341

from the reactors during 1968 was $140 \mathrm{pCi} / \mathrm{g}$, as compared with $260 \mathrm{pCi}{ }^{32} \mathrm{P} / \mathrm{g}$ during 1967 . (3) The lower average ${ }^{32} \mathrm{P}$ concentration in 1968 was attributed to decreased concentrations of ${ }^{32} \mathrm{P}$ in the river and decreased river temperatures.

RADIOACTIVITY IN THE ATMOSPHERE

A t Hanford, gaseous wastes from the chemical separations facilities are released to the atmosphere through elevated stacks after most of the radioactive materials have been removed. Laboratory stacks, reactor-building stacks, and stacks from waste storage facilities release relatively minor amounts of radioactive materials under normal operating conditions. Figure 6 shows the locations of offsite air sampling stations.

Measurements of airborne ${ }^{131}$ I, the radionuclide of primary interest, were made routinely during 1968 at about 30 locations within and near the Hanford reservation. Figure 7 shows the data from offsite air samples from nearby locations in the direction of the prevailing wind (Southeast Quadrant). The results of ${ }^{131}$ I measurements for four selected locations for the past few years, which include contributions from offsite weapons tests, are summarized in Table 8 , with a more detailed tabulation in the Appendices. (2) The locations listed in Table 8 lie within a $45^{\circ}$ sector southeast to south of the separations areas. The environmental ${ }^{131}$ I concentrations for 1968 averaged less than the analytical $1 \mathrm{imit}$ of $0.02 \mathrm{pCi} / \mathrm{m}^{3}$ at Richland, Pasco, and Kennewick, A sustained concentration of ${ }^{131}$ I at this level in breathing air would imply an annual radiation dose to the thyroid of the Standard Man ${ }^{(20)}$ of less than 1 mrem from inspired air.*

* Assuming that volume breathing rate is proportionaz to thyroid size, the thyroid dose from inhalation of $131^{I}$ is independent of age and thyroid size.(28) 


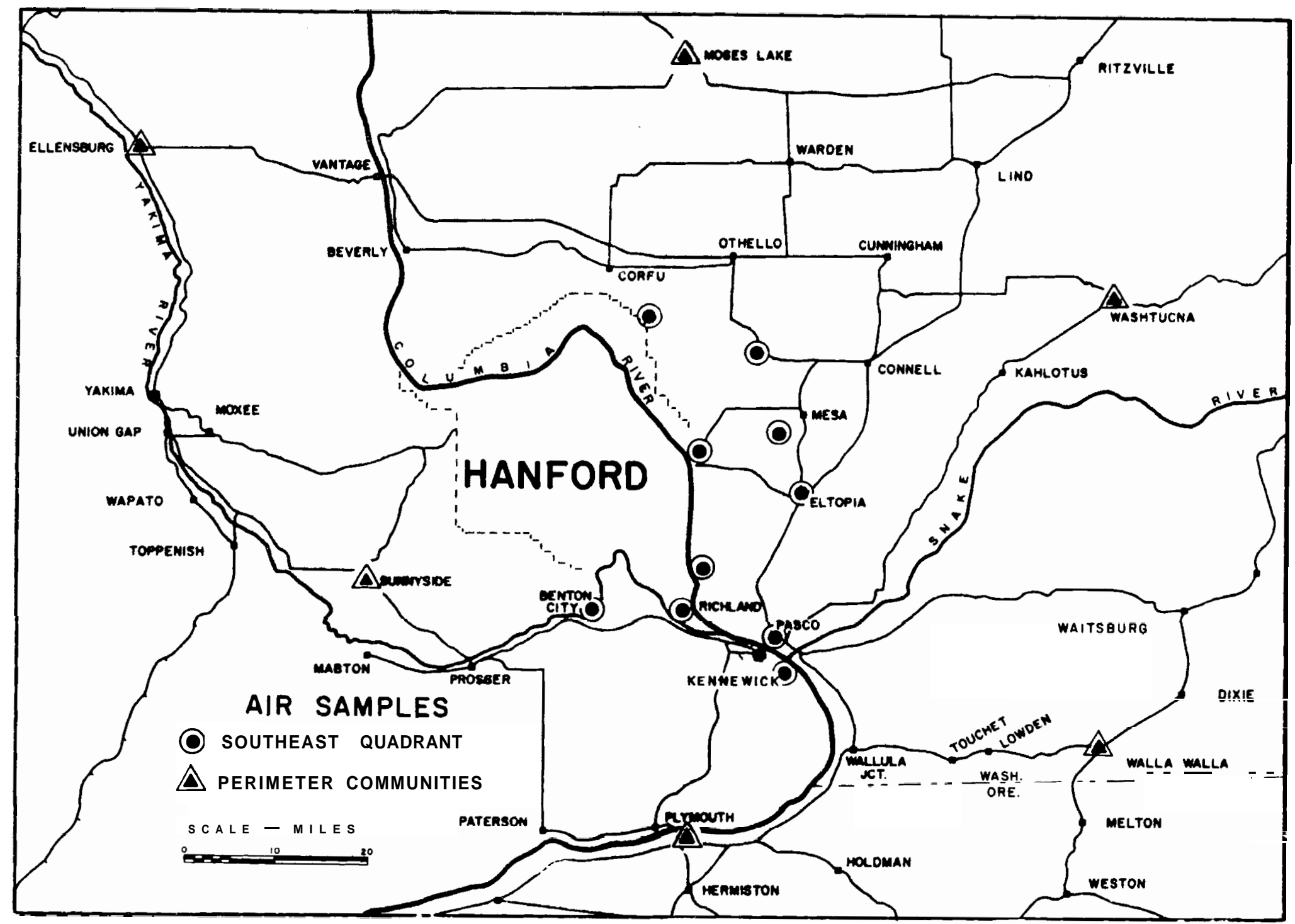

FIGURE 6. Offsite Air Sampling Locations 


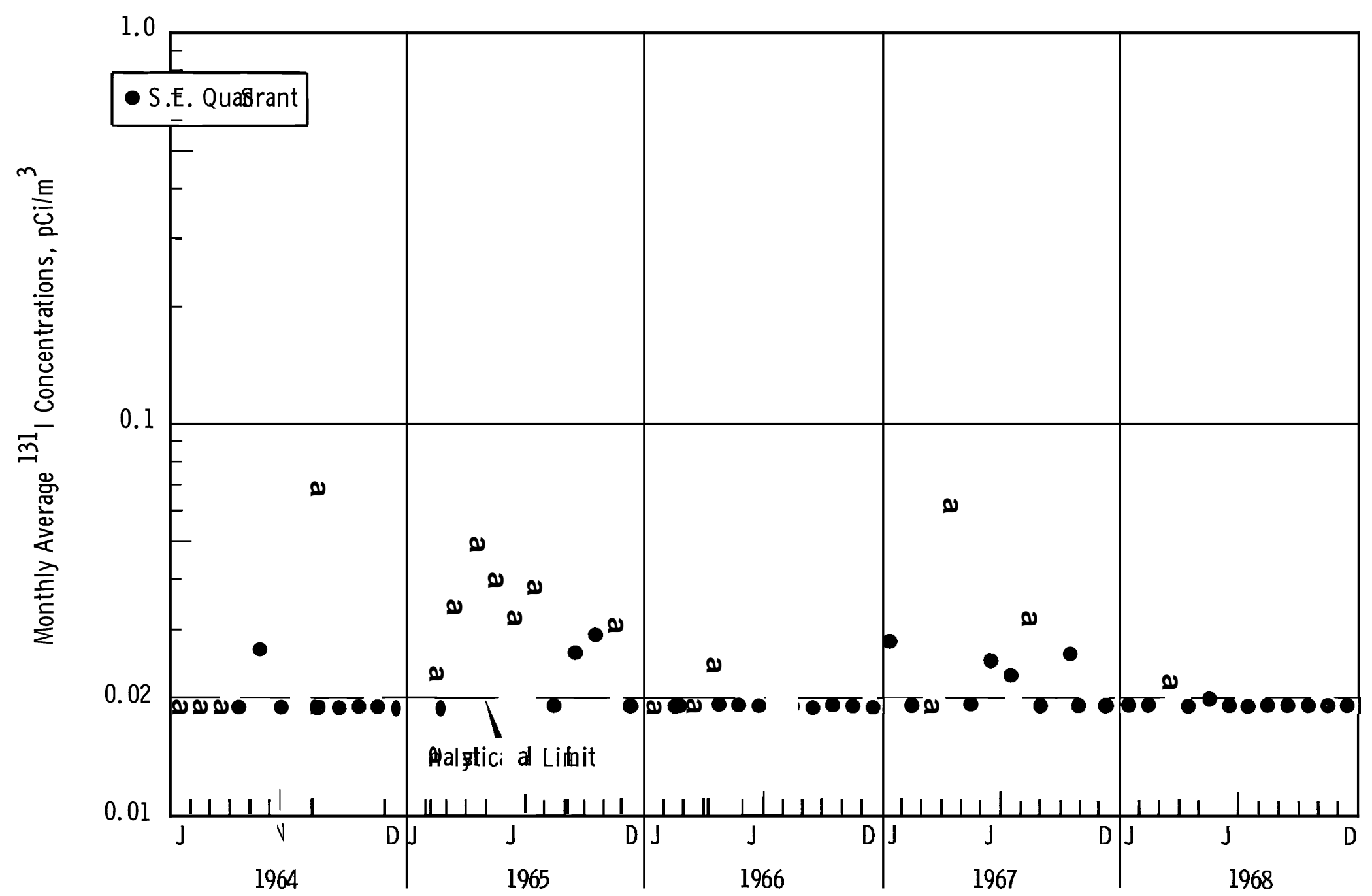

FIGURE 7. Monthly Average ${ }^{131}$ I Concentrations in the Air of Hanford Environs ( $\left.\mathrm{pCi} / \mathrm{m}^{3}\right)$ 
BNWL -1341

\begin{tabular}{|c|c|c|c|c|c|c|}
\hline TABLE 8 & $\begin{array}{l}\text { Annual Average } \\
\text { in the Atmosp } \\
\text { Distance } \\
\text { from Separation } \\
\text { Stacks, km } \\
\end{array}$ & $\begin{array}{c}{ }^{131} \text { I C } \\
\text { ere, }(p c \\
1968\end{array}$ & $m^{3}$ ) & ions & $\underline{1965}$ & $\underline{1964}$ \\
\hline $\begin{array}{l}\text { Prosser } \\
\text { Barricade }\end{array}$ & 23 & $0.01^{(b)}$ & 0.02 & 0.02 & 0.03 & 0.02 \\
\hline Benton City & 32 & 0.01 & 0.02 & 0.01 & 0.03 & 0.06 \\
\hline Rich 1 and & 32 & 0.02 & 0.02 & 0.01 & 0.02 & 0.02 \\
\hline Pasco & 51 & 0.02 & 0.02 & 0.01 & 0.03 & 0.01 \\
\hline
\end{tabular}
Concentration Guide (AEC Manual Chapter $0524,{ }^{(8)}$ Annex I,
Table II, Column 1) $-\frac{100 \mathrm{pCi} / \mathrm{m}^{3}}{100}$

b. Sampling at Prosser Barricade was discontinued in April 1968.

Continuous sampling for radioactivity associated with airborne particulates was maintained as of the end of 1968 at 35 locations, including those within the Hanford reservation and around the plant perimeter at distances up to 75 miles. The gross beta activity of each sample filter was routinely measured (based on ${ }^{90} \mathrm{Sr}-\mathrm{Y}$ calibration) with detailed radioanalyses performed on filters showing unusual beta activity.

Figure 8 shows average total beta concentrations for the group of samples collected from the Southeast Quadrant and from other more distant locations (Perimeter Communities), with a complete tabulation in the Appendices. (2) The higher atmospheric concentrations of radioactive particulate material during the first half of 1968 compared to fall 1967 were attributed primarily to fallout following a foreign nuclear weapons test in late December 1967. The observed concentrations were comparable to those observed during similar events of recent years. A similar increase in total beta concentrations was noted in December 1968, however, no significant increase was noted in the southeast quadrant locations because of the nonuniform 
BNWL- 1341

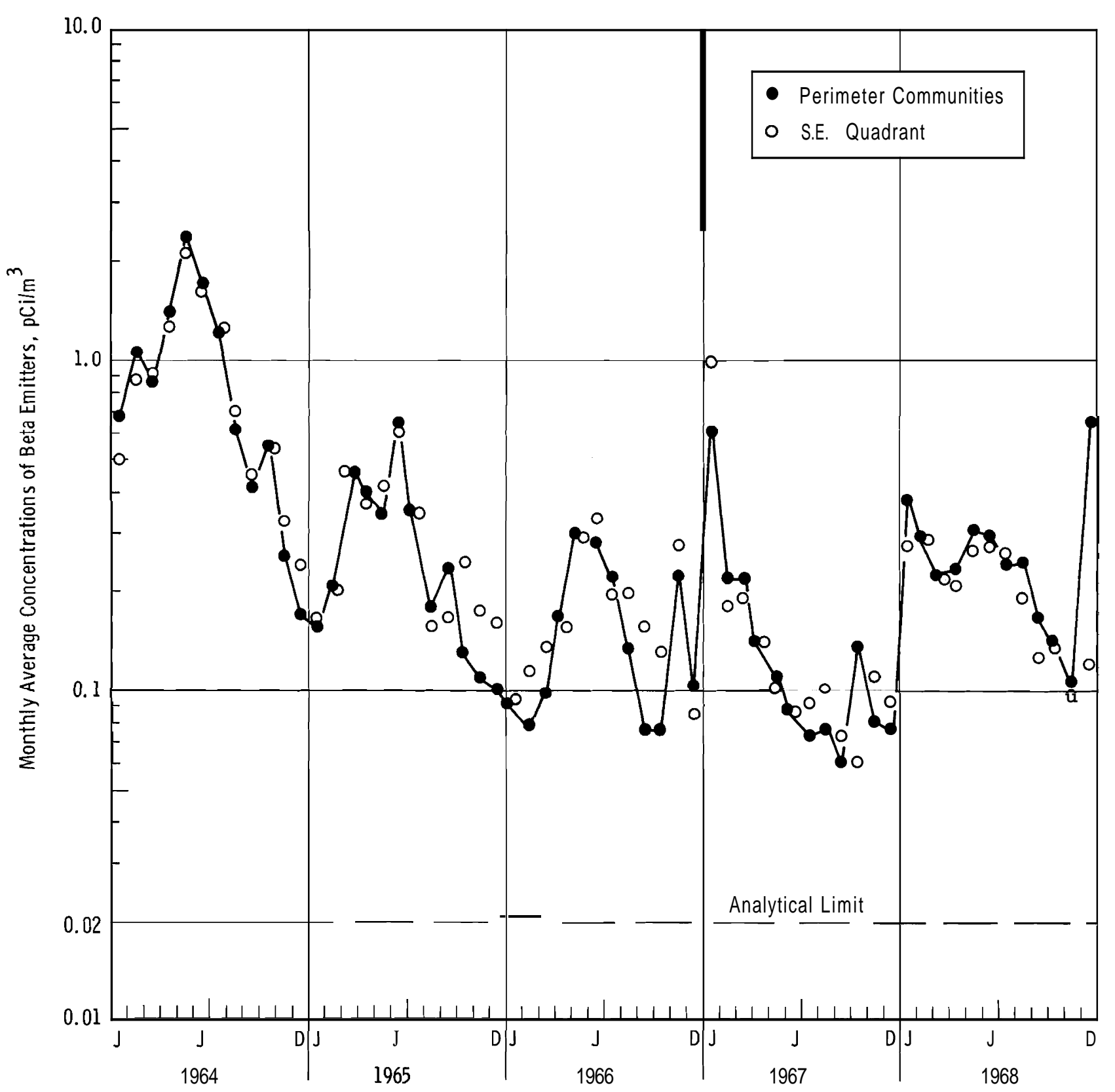

FIGURE 8. Monthly Average Particulate Total Beta Concentrations in the Air of Hanford Environs $\left(\mathrm{pCi} / \mathrm{m}^{3}\right)$ 
geographical distribution of the increased concentrations. The increase was attributed to fallout from an offsite source and the contaminant was identified as radiotungsten.

RADIOACTIVITY I N GROUNDWATER

Radioactivity in the groundwater beneath the Hanford project results primarily from ground disposal of wastes in the chemical separations areas. These wastes are routed to various facilities, dependent upon their radionuclide burden and chemical content. High-level wastes* are stored in underground concrete tanks lined with steel. Intermediate-level wastes*" are sent to underground "cribs" (covered liquid waste disposal sites) from which they percolate into the soil. The areas selected for intermediate-level waste disposal and high-level waste storage have soil with good ion exchange capacity and groundwater depths of 50 to $100 \mathrm{~m}$. Low-level wastes $\mathrm{t}$ are usually sent to depressions in the ground where surface ponds or "swamps" have been formed as the result of the continuous addition of relatively large volumes of water.

One important objective in the management of wastes placed in the ground is the prevention of radiologically important radionuclides from reaching the groundwater in quantities that could ultimately cause significant human radiation exposure should they migrate to the Columbia River. An extensive groundwater surveillance program is maintained at Hanford to aid in achieving this objective. Hundreds of wells have been drilled at various locations around the Hanford project, including sites within and near crib and tank storage areas, to monitor the movement of radionuclides in the groundwater.

\footnotetext{
* High-level: $\quad>100 \mu \mathrm{Ci} / \mathrm{ml}$

* Intermediate-level: $50 \mathrm{pCi} / \mathrm{ml}$ to $100 \mathrm{\mu Ci} / \mathrm{ml}$

+ Low-zever: $<50 \mathrm{pCi} / \mathrm{mz}$
} 
The radioactivity in groundwater from the chemical separations areas outside the immediate vicinity of the disposal sites is primarily ${ }^{3} \mathrm{H}$ and ${ }^{106} \mathrm{Ru}-\mathrm{Rh}$, although ${ }^{60} \mathrm{Co}$ and ${ }^{99} \mathrm{Tc}$ have also been found but at much lower concentrations. The more radiotoxic nuclides, such as ${ }^{90} \mathrm{Sr}$, have not been detected in groundwater except in the immediate vicinity of a few specific disposal sites.

Figures 9 and 10 show the probable extent of detectable ${ }^{3} \mathrm{H}$ and ${ }^{106} \mathrm{Ru}-\mathrm{Rh}$ in groundwater beneath the Hanford project as of December 31, 1968. (29) The outer boundaries of the contamination contours, e.g., $0.1 \% \mathrm{CG}^{*}$ for ${ }^{3} \mathrm{H}$ and $2 \% \mathrm{CG}$ for ${ }^{106} \mathrm{Ru}-\mathrm{Rh}$, represent the detection levels rountinely achievable for these radionuclides.

In a 11 probability, some radionuclides from the chemical processing areas are presently entering the Columbia River. However, the concentrations of these nuclides are too small to be routinely measurable in the groundwater near the river or in the river itself, and any radiation dose from them is negligible.

\section{FALLOUT FROM NUCLEAR WEAPONS TESTS}

Fresh fallout in early 1968 resulted from an announced(4) foreign nuclear weapons test in December, 1967. Airborne particulate radioactivity concentrations (Figure 8) were higher during the first half of 1968 as a result of the December 1967

concentration Guide (GGI is the new terminology of the AEC Manual Chapter 0524(7) and is equivalent to the term Maximum Permissibze Concentration (MPC) as used in previous reports $i n$ this series. The Concentration Guide (CG) referred to $i s$ that for continuous exposure to individual members of the public. It is only one-tenth that permitted for occupational exposure, but about three times the concentration permitted for a suitable sample of the exposed population. 


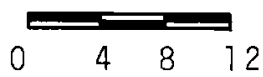

$\mathrm{Ki} 1$ ometers
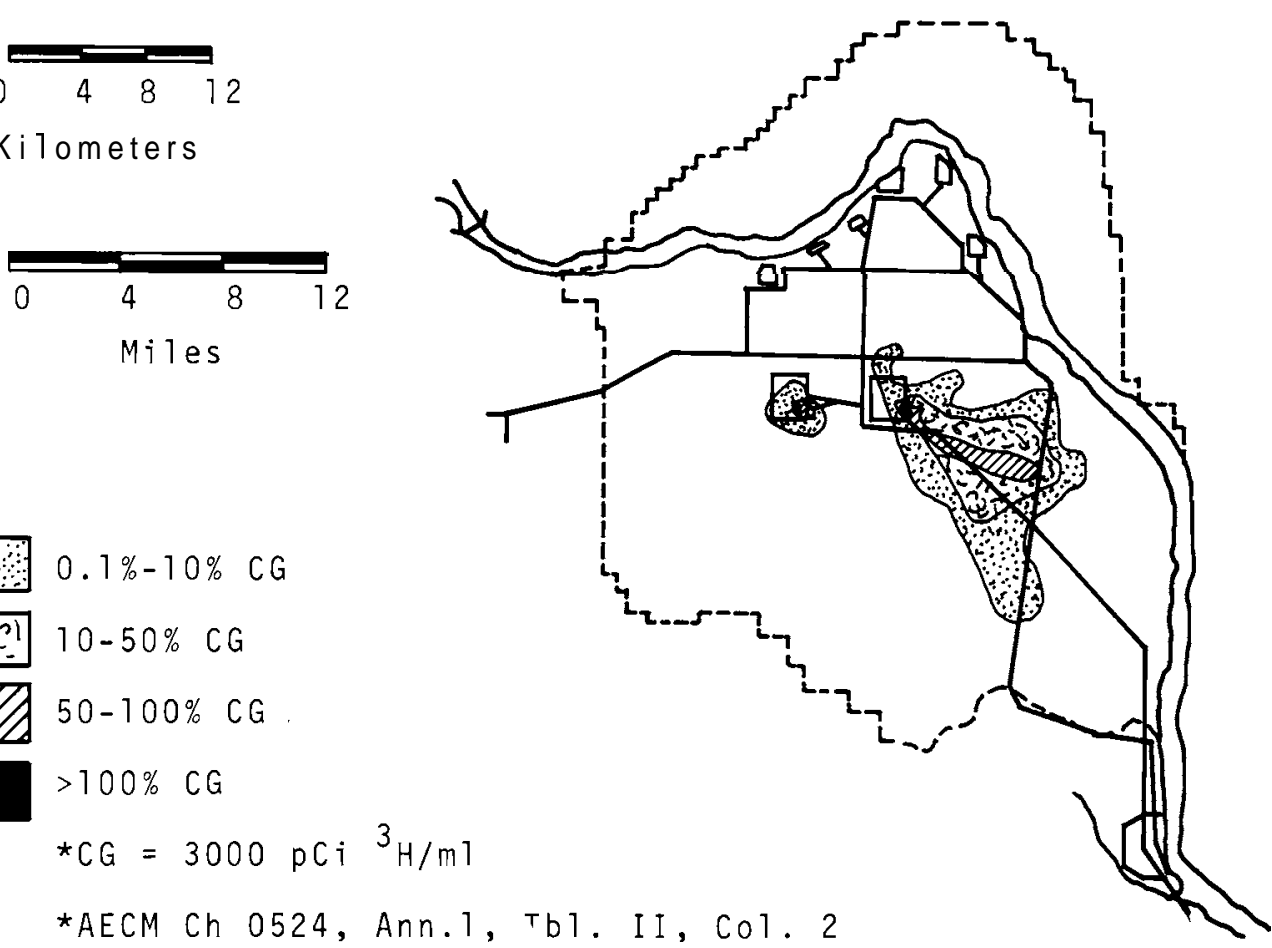

FIGURE 9. 3 H Concentrations in Ground Water - JulyDecember, 1968

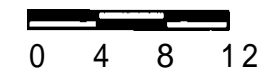

Ki 10 meters
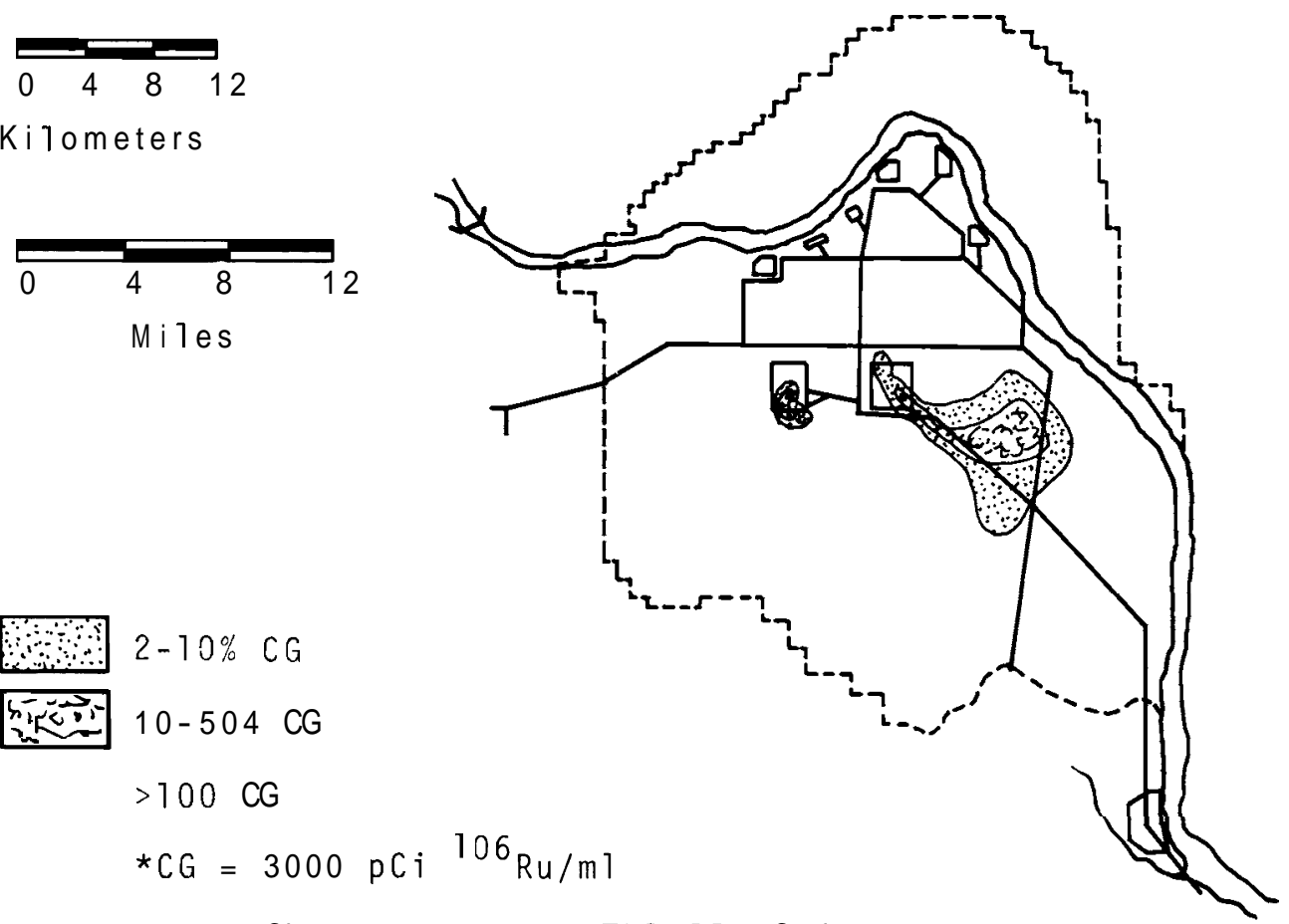

$2-10 \% \quad C G$
$10-504 \quad C G$
C

$>100 \mathrm{CG}$

${ }^{*} \mathrm{CG}=3000 \mathrm{pCi}{ }^{106} \mathrm{Ru} / \mathrm{ml}$

*AECM Ch 0524, Ann.1, Tb1.II, Col. 2

FIGURE 10. ${ }^{106} \mathrm{Ru}$ Concentrations in Ground Water - JulyDecember, 1968 
event. Atmospheric concentrations of ${ }^{131} \mathrm{I}$ (Figure 7) were within the normal range of fluctuation from plant sources, but ${ }^{131} \mathrm{I}$ concentrations in milk samples reached a peak of $25 \mathrm{pCi} /$ liter in January. For comparison, in January 1967, the peak ${ }^{131}$ I concentration in milk was $83 \mathrm{pCi} / 1 \mathrm{iter}$ as a result of fallout from a foreign weapons test in December 1966.

In December, a general increase in beta activity in the atmosphere was attributed to regional fallout from an event at the Nevada Test Site (4) with the highest concentration of particulate radioactivity $\left(3.9 \mathrm{pCi} / \mathrm{m}^{3}\right)$ at Walla Walla during the period December 6 through December 20. The principal gamma-emitter was identified as radiotungsten.

No significant contribution to atmospheric radiation levels was detected in December samples following the announced( 30$)$ foreign nuclear weapons test of December 27, 1968.

Routine measurements in foods of the fallout nuclides ${ }^{131} \mathrm{I},{ }^{90} \mathrm{Sr}$, and ${ }^{137} \mathrm{Cs}$ are discussed in Exposure Pathways, page 54.

Concentrations of ${ }^{3} \mathrm{H}$ in river water are measured upstream from Hanford at Priest Rapids Dam and downstream from Hanford at Richland. The average concentrations of ${ }^{3} \mathrm{H}$ at Priest Rapids Dam and Richland were not significantly different at 1.6 and $1.7 \mathrm{nCi} / 1$ iter, respectively, compared to 1.4 and $1.5 \mathrm{nCi} / 1 \mathrm{iter}$ at these locations during 1967. 


\section{EXPOSURE PATHWAYS}

RADIONUCLIDES IN DRINKING WATER

The city of Richland is the first community downstream from the Hanford reactors that uses the Columbia River as a source of drinking water. Pasco and Kennewick, a few kilometers farther downstream, also use the Columbia River as a source of drinking water. The Richland and Pasco water plants use a modern flocculation-filtration method; Kennewick water is pumped from Rainey well collectors (infiltration pipes) laid in the riverbank. During 1968, cumulative drinking water samples were collected at the Richland and Pasco water plants, and periodic samples at all three communities. All of these samples were analyzed for important individual radionuclides. Detailed analyses of drinking water from these three cities are available in the Appendices, (2) and are summarized in Table 9. In June, analyses of individual radionuclides in samples from Kennewick were discontinued because previous experience has shown that concentrations of radionuclides in Kennewick water are significantly lower than at Pasco or Richland. Kennewick samples continued to be analyzed for gross beta.

The concentrations of short-lived radionuclides in the water at the time it is consumed are less than shown in Table 9 because there can be a significant transport time between the water plant and most consumers. The transport time may vary from hours to days depending upon the location of the customers on the distribution system and the water demand. In Richland, many residents receive no radioactivity of Hanford origin in drinking water during the times of the year when well water is used to supplement the system supply.

Table 10 presents calculated doses to the adult whole body, GI tract, and bone from sustained consumption at a standard 
BNWL -1341

TABLE 9. Average Concentrations (a) of Several Radionuclides in Drinking Water, 1968 (pCi/liter)

\begin{tabular}{|c|c|c|c|}
\hline Radionuclide & Richland & Pasco & Kennewick (b) \\
\hline$R E+Y^{(c)}$ & 46 & 20 & 9 \\
\hline${ }^{24} \mathrm{Na}$ & 1600 & 350 & 140 \\
\hline $32 \mathrm{P}$ & 48 & 30 & 13 \\
\hline${ }^{51} \mathrm{Cr}(\mathrm{d})$ & 1400 & 1400 & 480 \\
\hline${ }^{64} \mathrm{Cu}$ & 350 & $<51$ & 38 \\
\hline $65_{\mathrm{Zn}}(\mathrm{d})$ & 38 & 35 & $<24$ \\
\hline${ }^{76}$ As & 140 & 33 & 15 \\
\hline $90 \mathrm{Sr}$ (d) & $<0.6$ & $<0.5$ & $\ldots$ \\
\hline $122 \mathrm{Sb}$ & 120 & 100 & 22 \\
\hline $131_{I}(d)$ & 6.9 & 5.9 & $<2$ \\
\hline${ }^{133} \mathrm{I}$ & $41^{(\mathrm{e})}$ & $24^{(f)}$ & --- \\
\hline${ }^{239} \mathrm{~Np}$ & 670 & 340 & 57 \\
\hline $\begin{array}{l}\text { Total Beta, } \\
\text { counts } / \mathrm{min} / \mathrm{m} 1\end{array}$ & 2.9 & 1.2 & 0.3 \\
\hline
\end{tabular}

a. Measured at the water plants

b. Kennewick concentrations were based on monthly grab samples collected January through June except for total beta which was based on weekly grab samples throughout the year

c. See Table 4 for definition

d.. Results based on cumulative samples at Richland and Pasco

e. Estimate baeed on an average ratio of ${ }^{133} I /{ }^{131}$ I of $6: 1$ measured in grab samples

f. Estimate based on an average ratio of ${ }^{133}$ I/ ${ }^{131}$ I of $4: 1$ measured in grab samples 
TABLE 10. Calculated Annual Doses to Selected Organs from Routine Ingestion of Drinking Water, (a) 1968 (mrem)

\begin{tabular}{|c|c|c|c|c|}
\hline & Whole Body & GI Tract & Bone & $\begin{array}{l}\text { Thyroid (Infant) } \\
0.4 \text { liters/day }\end{array}$ \\
\hline Richland & 1.5 & 18 & $\begin{array}{c}4.0 \\
(0.1 \% \mathrm{MPRI})\end{array}$ & 48 \\
\hline Pasco & 0.5 & 12 & $\begin{array}{c}2.5 \\
(<0.1 \% \text { MPRI })\end{array}$ & 32 \\
\hline
\end{tabular}

intake of 1.2 liters/day, and to the infant 2 g thyroid from consumption of 0.4 liters/day of drinking water in Richland and Pasco. Average concentrations of radionuclides measured at the water plants were used to calculate these doses. However, thrice-weekly measurements of gross beta activity were also used in establishing the GI-tract dose. .

The dose estimates for Pasco residents reflect a downward trend from 1967. The thyroid dose for 1968 from Pasco drinking water (32 mrem) was slightly less than that for 1967 (35 mrem) because. of the decreased concentration of ${ }^{131} \mathrm{I}$. The average ratio of ${ }^{133} I /{ }^{131}$ I of $4: 1$ for Pasco in 1968 which was based on 1968 measurements on grab samples was the same as the assumed ratio in 1967.

The estimated GI tract dose to Richland residents from the measured radionuclides in drinking water was somewhat lower in 1968 (18 mrem) than in 1967 (28 mrem) as a result of the decreased concentrations of most measured radionuclides and a decrease in the average gross beta activity from 4.7 in 1967 to 2.9 counts $/ \mathrm{min} / \mathrm{m} 1$ in 1968 . The infant thyroid dose appears somewhat higher during 1968 than during $1967^{(3)}$ because the estimated contribution of ${ }^{133}$ I was based on an assumed ratio of ${ }^{133}$ I to 
BNWL -1341

${ }^{131}$ I of 4:1 in 1967. Measurements during 1968, however, indicated a slightly higher ratio $(6: 1)$. Without the increment from ${ }^{133} \mathrm{I}$, the estimated thyroid dose for 1968 would have been lower than for 1967.

Figure 11 shows the relative contribution of several radionuclides in the Richland drinking water to the calculated annual dose to the GI tract, and Figure 12 shows long-term trends in the GI tract dose from Pasco and Richland drinking water.

\section{RADIONUCLIDES IN COLUMBIA RIVER FISH}

The quantities and kinds of fish caught by local fishermen have been previously estimated from surveys carried out from 1963 to 1965 in cooperation with the Washington State Game Department. The maximum estimate of consumption by the fishermen interviewed was 200 meals/yr of panfish species (crappie, perch, and bass) taken from the Columbia River. Additional dietary data collected during 1966 and 1967 from household questionnaires and interview surveys (31) also showed individual consumption estimates as high as 200 meals of fish per year. The primary fishing locations for the catch of these fish were Burbank, Hover-Finley, and Island View (see Figure 2). The average percentage of the maximum catch by species was $73 \%$ crappie, $16 \%$ bass, and $11 \%$ perch.

From this species distribution and radiochemical analyses of the specimens collected, (2) the Maximum Individual ${ }^{1} \mathrm{~s}$ estimated intakes during 1968 were $1.0 \mu \mathrm{Ci}{ }^{32} \mathrm{P}$ and $0.4 \mu \mathrm{Ci}{ }^{65} \mathrm{Zn}$.

The average consumption of Columbia River fish by Richland residents was estimated from plant employee diet questionnaires. (3) With the use of the same mixture of species as for the Maximum 


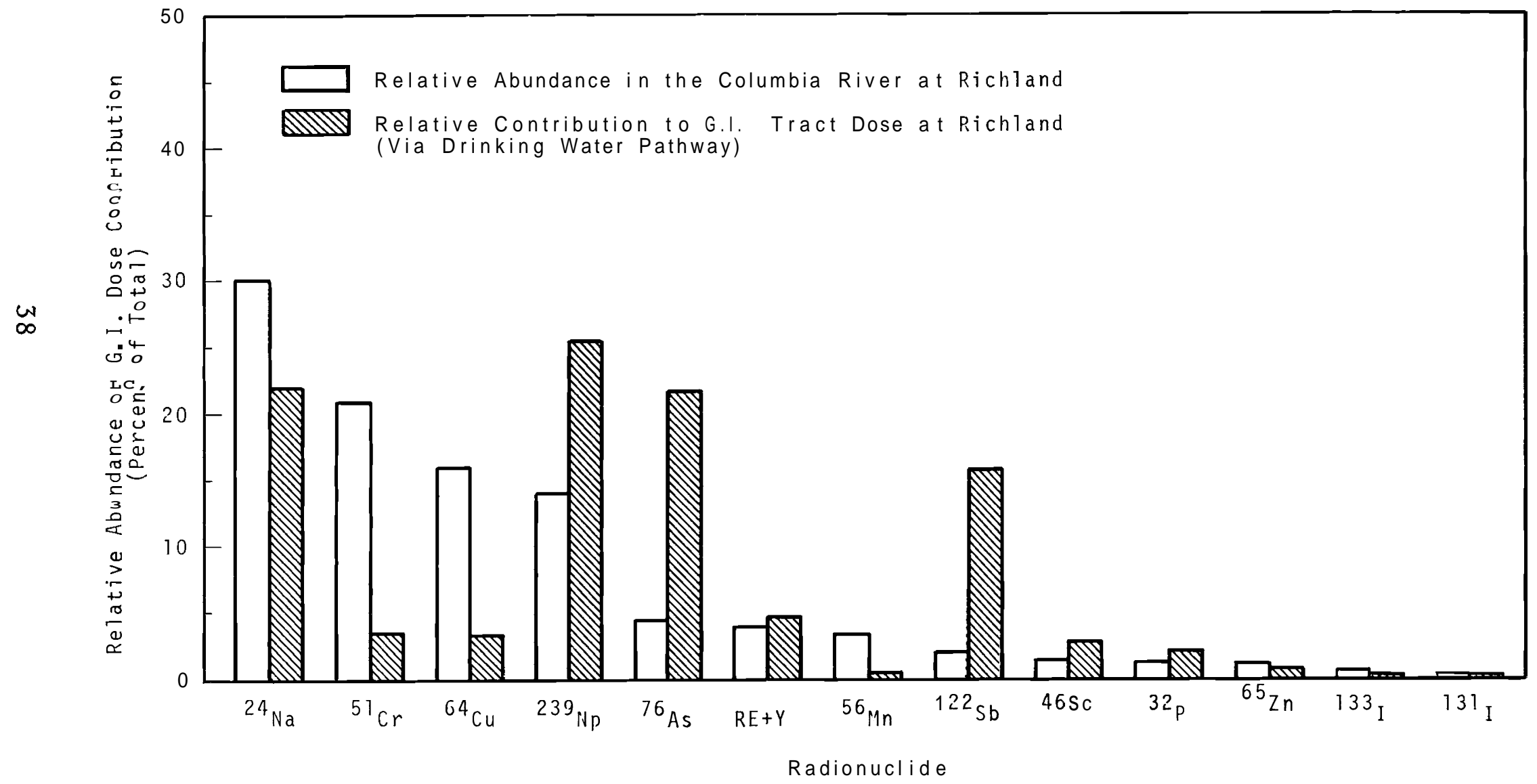

FIGURE 11. Relative Contribution of Various Radionuclides in Richland Drinking Water to the GI Tract Dose for 1968 


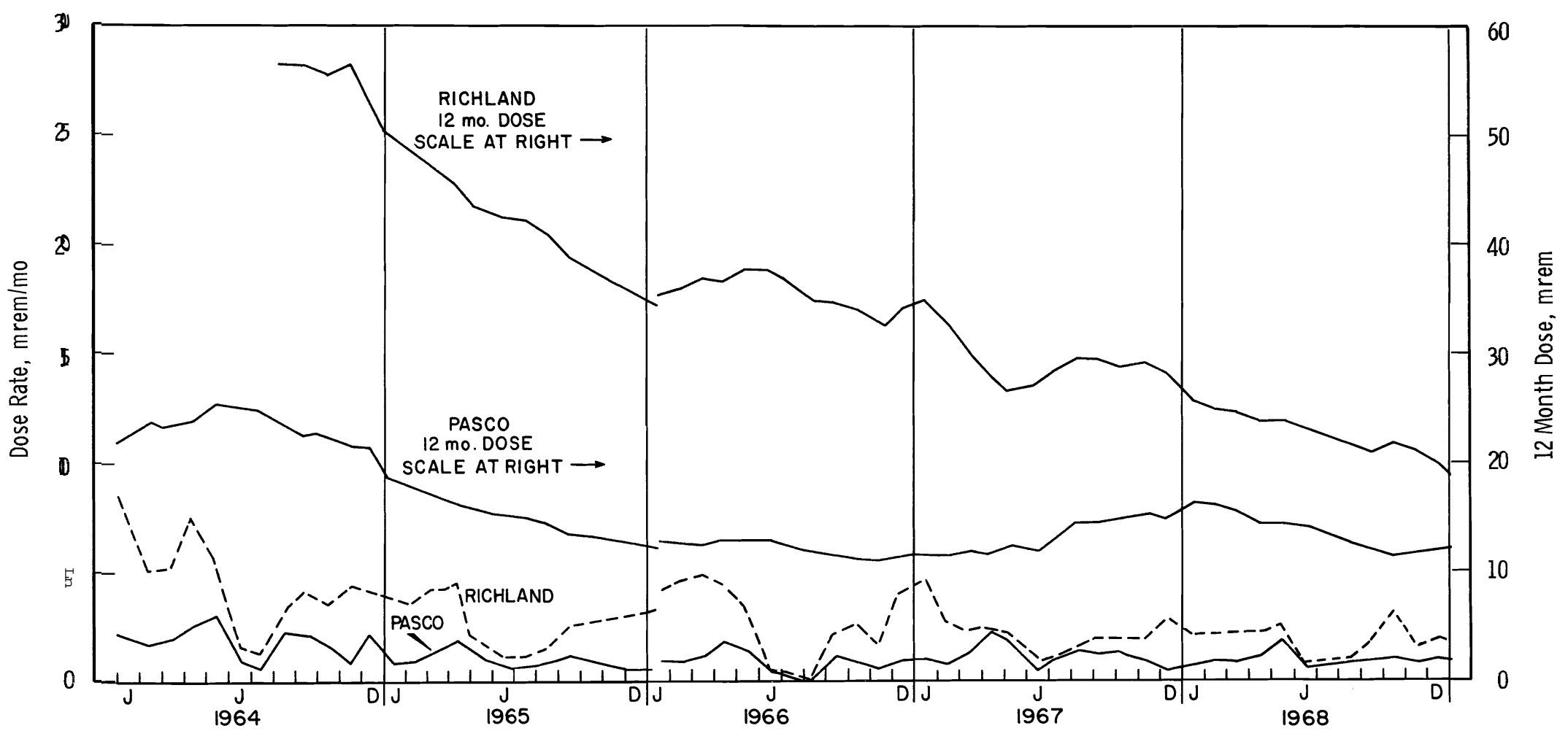

FIGURE 12. Doses to the GI Tract from Richland and Pasco Drinking Water (1.2 liter/day intake rate) 
Individual, the Average Richland Resident's intake during 1968 was $0.012 \mu \mathrm{Ci}{ }^{32} \mathrm{P}$ and $0.004 \mu \mathrm{Ci}{ }^{65} \mathrm{Zn}$. Such an intake corresponds to a bone dose of slightly more than 2 mrem or about $0.5 \%$ of the standard of $500 \mathrm{mrem} / \mathrm{yr}$ for the population average. For comparison, intakes during 1967 were $0.019 \mu \mathrm{Ci}{ }^{32} \mathrm{P}$ and 0.004 $\mu \mathrm{Ci}{ }^{65} \mathrm{Zn}$.

\section{RADIONUCLIDES IN GAME BIRDS}

Migratory waterfowl utilizing the river downstream from the reactors and upland game birds living near the river may be a significant source of the bone-seeking radionuclides ${ }^{32} \mathrm{P}$ and $65 \mathrm{Zn}$ for persons who consume such birds. The concentrations of radionuclides in game birds at the time of consumption are dependent upon the bird species, the geographical locations of the birds, and the elapsed time between killing and consumption of the birds.

For the past two years, about $16 \mathrm{~km}^{2}$ (4000 acres) of the Hanford site situated north of Ringold on the eastern side of the Columbia River has been opened to hunters during hunting season. This area which is adjacent to the river was visited in 1968 by 1537 hunters for an average of about 33 hunters on each of the 46 open days. (32) For comparison, the average for 1967 was about 50 hunters on each of the 48 open days. (32)

The average concentration of ${ }^{32} \mathrm{P}$ in the muscle (the edible portion) of waterfowl collected at the Hanford site for the environmental monitoring program during 1968 was about $53 \mathrm{pCi} / \mathrm{g}$ for ducks and $1.4 \mathrm{pCi} / \mathrm{g}$ for geese. The maximum concentration in waterfowl during 1968 was $450 \mathrm{pCi}^{32} \mathrm{P} / \mathrm{g}$, which is significantly lower than the maxima observed in the past few years. Average concentrations in muscle for upland game birds collected at the Hanford site appear in Table 11. The maximum ${ }^{32} \mathrm{P}$ concentration in upland game bird muscle was $490 \mathrm{pCi}{ }^{32} \mathrm{P} / \mathrm{g}$ in a quail sample. If a small child ( $2 \mathrm{~kg}$ skeleton) had immediately consumed $100 \mathrm{~g}$ of this quail, the resultant bone dose would be about 30 mrem or $2 \%$ of the standard. 
BNWL- 1341

TABLE 11. Average ${ }^{32} \mathrm{P}$ and ${ }^{65} \mathrm{Zn}$ Concentrations
in Muscle of River Birds (pCi/g)

$\underline{\text { Species }}$

Duck

Goose

Quail

Pheasant

Chukar

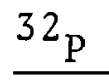

53

1.4

41

10

10.1
$65_{\mathrm{Zn}}$

3.3

1.5

3.5

4.9

5.2

a. Collected within $5 \mathrm{~km}$ ( 3 miles) of the Columbia River within the Hanford boundary.

Data from a dietary survey of Hanford employees (3) and from a special survey of local hunters, (33) and concentration data for the various species ${ }^{(2)}$ have been combined in Tables 12 and 13 . About $30 \%$ of the game bird meals consumed by local hunters were reported to be birds shot within about $5 \mathrm{~km}$ (3 miles) of the Columbia River between Ringold and McNary Dam. Analyses showed that pheasants collected beyond this distance contained little if any radioactivity of Hanford origin. About $44 \%$ of all birds eaten were reported to have been placed in frozen storage which would permit appreciable decay of ${ }^{32} \mathrm{P}$ before consumption.

The maximum total game bird consumption by adults reported to date is 100 meals/yr, which we assume to be about $23 \mathrm{~kg} / \mathrm{yr}$. Consumption of this weight of the average game bird meal (Table 12) would result in intakes of $0.09 \mu \mathrm{Ci}{ }^{32} \mathrm{P} / \mathrm{yr}$ and $0.04 \mu \mathrm{Ci}{ }^{65} \mathrm{Zn} / \mathrm{yr}$, implying 14 mrem to the skeleton of a Standard Man or $1 \%$ of the standard for individual members of the population with bone as the critical organ. Consumption of the estimated annual intake ( $1.24 \mathrm{~kg} / \mathrm{yr})$ for the Average Richland Resident (adult) would result in a total dose of less than 1 mrem to the skeleton. 


\section{TABLE 12. Species Distribution of Local Game Birds}

Duck, Goose, Quail, Pheasant, Grouse, Dove, $\% \frac{\%}{\%}-\frac{\%}{\%}-$

River Birds (a)

of Each

Species

37

32

19

33

8

20

Meals of

Each Species

of A 11 Bird

Meals

23

6

12

47

13

No

River Bird (a)

Meals of Each

Species of All

Bird Meals

$8.5 \quad 1.8$

2.3

16

$<1$

No

Data

a. River birds are defined to be birds shot within $5 \mathrm{~km}$ ( 3 miles) of the Columbia River between Ringold and MoNary Pam.

TABLE 13. Contribution (a) of Each Species to $100 \mathrm{~g}$ of an Average Game Bird Meal

\begin{tabular}{|c|c|c|c|}
\hline Species & Weight, g & ${ }^{32} \mathrm{P}$. & ${ }^{55} \mathrm{Zn}$ \\
\hline Duck & 23 & 252 & 28 \\
\hline Goose & 6 & 2 & 3 \\
\hline Quail & 12 & 52 & 8 \\
\hline Pheasant & 47 & 91 & 76 \\
\hline Grouse & 13 & 5 & 1 \\
\hline Total & 100 & 402 & 120 \\
\hline
\end{tabular}

a. Weighted for location of kizz by using measured concentrations for river birds and assuming no $32 \mathrm{P}$ or $65 \mathrm{Zn}$ in other birds. Also weighted for frozen storage by assuming complete decay of $32 \mathrm{P}$, but no significant decay of $65 \mathrm{Zn}$ during frozen storage of $44 \%$ of the birds. 
BNWL -1341

\section{RADIONUCLIDES IN SHELLFISH}

${ }^{65} \mathrm{Zn}$ and ${ }^{32} \mathrm{P}$ are the only radionuclides in the reactor effluent that are found in sufficient abundance in food organisms beyond the mouth of the Columbia River to be of radiological interest. Oysters have been found to contain higher concentrations of ${ }^{65} \mathrm{Zn}$ than other common seafoods. (34) Monthly average concentrations of ${ }^{65} \mathrm{Zn}$ and ${ }^{32} \mathrm{P}$ periodically measured in oysters grown commercially in the Willapa Bay area are shown in Figure 13; the analytical results for 1968 are tabulated in the Appendices. (27) A normal seasonal minimum for ${ }^{32} \mathrm{P}$ occurs in the late summer. In $1968,{ }^{32} \mathrm{p}$ average concentrations remained at or below $1 \mathrm{pCi} / \mathrm{g}$ and from August through December as in 1967. The annual average concentrations for 1968 were $25 \mathrm{pCi}{ }^{65} \mathrm{zn} / \mathrm{g}$ and $3.3 \mathrm{pCi}^{32} \mathrm{P} / \mathrm{g}$.

Consumption of oysters containing the 1968 average concentrations at the rate of $50 \mathrm{~g} /$ day ${ }^{(35)}$ would result in annual doses of about 5 mrem to the GI tract, 3 mrem to the whole body, and 8 mrem to the bone of a Standard Man. (20) Fresh shellfish are not an important item in the average Tri-Cities diet, but residents of some coastal areas may consume more than the reference value of $50 \mathrm{~g} /$ day. For such individuals, shellfish are assumed to be their only source of radionuclides of Hanford origin.

RADIONUCLIDES I N MILK AND PRODUCE

Irrigation with river water containing reactor effluent radionuclides can influence the radioactivity found in locally grown products. Deposition of airborne materials from Hanford sources and from fallout can be an additional source of radionuclides in these products. Chemical separations facilities are generally the principal local source of airborne radionuclides, although radioactive materials released from ventilation stacks of reactor or laboratory facilities could, under certain conditions, be of interest. 


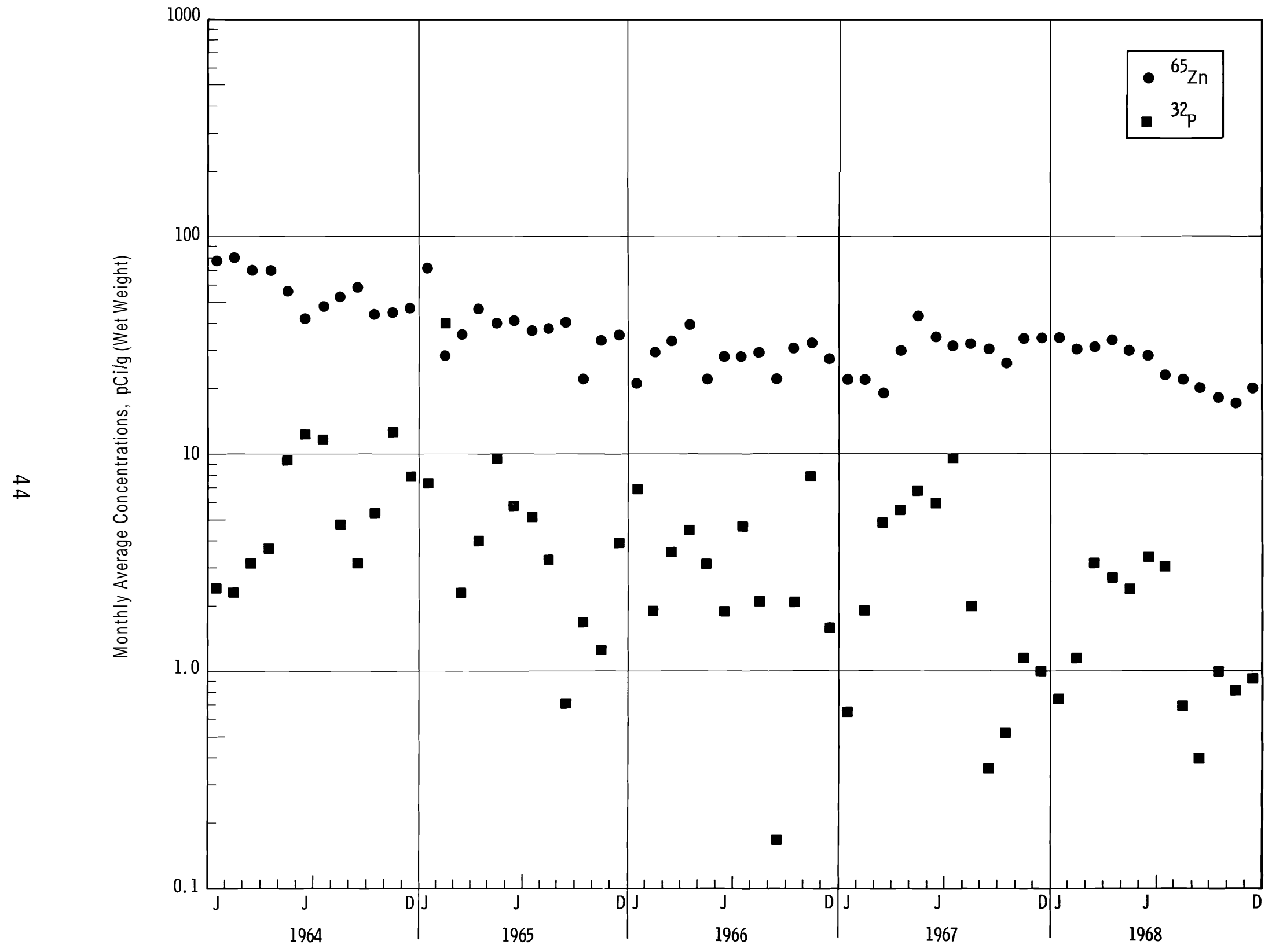

FIGURE 13. ${ }^{32} \mathrm{P}$ and ${ }^{65} \mathrm{zn}$ Concentrations in Willapa Bay Oysters (pCi/g, Wet Weight) 
The farming area closest to the separations facilities is at Ringold about $21 \mathrm{~km}$ (13 miles) away. However, much of the land east and south of the project boundary (see Figure 2) is under cultivation and may be in the path of airborne releases.

Most irrigated farms near the Hanford plant obtain water from the Yakima River, or from the Columbia River above the plant. However, two small irrigated areas using Columbia River water taken downstream from the reactors are the Ringold farms and the Riverview district west of Pasco. They are 40 and $65 \mathrm{~km}$ (25 and 40 miles), respectively, downstream from the operating reactors. The Ringold farms, about $21 \mathrm{~km}$ east of the separations areas, involve some 20 people working $2 \mathrm{~km}^{2}$ (500 acres) of land with fruit as the principal product. The Riverview district comprises about $21 \mathrm{~km}^{2}$ (5300 acres) supporting about 1000 families, the majority of which live on plots of $4000 \mathrm{~m}^{2}$ ( 1 acre) or less and raise family gardens. The principal products from the larger farm plots are hay, fruit, beef, and dairy products. This area is centered $40 \mathrm{~km}$ ( 25 miles) southeast of the chemical separations plants.

The milk surveillance program maintained during 1968 included samples from local farms and dairies and from commercial supplies available to people in the Tri-Cities. The concentrations of radionuclides found in milk sold by commercial outlets were similar to those reported by the U.S. Public Health Service (36) and the Washington State Department of Health. (37) Milk from local farms irrigated with water drawn from the river downstream from the reactors contained ${ }^{32} \mathrm{P},{ }^{65} \mathrm{Zn}$, and ${ }^{131} \mathrm{I}$ as well as fission products of fallout origin. Commercial milk distributed in the Tri-Cities usually does not contain detectable ${ }^{32} \mathrm{P}$ and ${ }^{65} \mathrm{Zn}$ because the vast majority of milk is produced on farms not irrigated with Columbia River water. 
Figure 14 shows the monthly average concentrations of ${ }^{32} \mathrm{P}$ and ${ }^{65} \mathrm{Zn}$ in milk from river-irrigated farms in the Ringold and Riverview areas. Monthly averages for 1968 represent data from two farms in Riverview, one of which was sampled in 1967. During 1968, the annual average ${ }^{32} \mathrm{P}$ concentration was $450 \mathrm{pCi} /$ liter compared to $320 \mathrm{pCi} /$ iter in 1967 as a result of inclusion of another sampling location in 1968. The 1968 annual average concentration of $65 \mathrm{zn}$ was $340 \mathrm{pCi} / 1 \mathrm{iter}$ compared to $200 \mathrm{pCi} /$ liter for 1967. Seasonal fluctuations in concentrations of both ${ }^{32} \mathrm{P}$ and ${ }^{65} \mathrm{zn}$, caused primarily by irrigation and feeding practices, followed expected trends.

Figure 15 shows the monthly average concentrations of ${ }^{131_{I}}$ in locally available milk. During 1968, ${ }^{131}$ I concentrations in both farm milk and commercial milk were generally near or below the analytical limit (3 pCi/liter). The maximum ${ }^{131}$ I concentration for the period ( 25 pCi/liter) was measured in a single sample of farm milk collected on January 17 and was attributed to increased worldwide fallout. The average concentration for the year in farm milk was $<1.5 \mathrm{pCi}{ }^{131}$ I/1iter.

Adult residents consuming milk ( 1 liter/day) obtained from the Riverview area could have received an annual dose from ${ }^{32} \mathrm{P}$ and ${ }^{65} \mathrm{Zn}$ amounting to about $4 \mathrm{mrem}$ to the GI tract, $2 \mathrm{mrem}$ to the whole body, and $32 \mathrm{mrem}$ to the bone. The same intake of milk by a child with a $2 \mathrm{~kg}$ skeleton would result in an estimated bone dose of 110 mrem. The intake of ${ }^{131}$ I would have resulted in a dose of about 9 mrem to the $2 \mathrm{~g}$ thyroid of an infant. Concentrations of radionuclides measured in milk are tabulated in the Appendices. (2)

* Based on dose factors of $660 \mathrm{mrem} / \mu \mathrm{Ci}$ for ${ }^{32} \mathrm{P}$ and $11 \mathrm{mrem} / \mathrm{\mu Ci}$ for $65 \mathrm{Zn}$ for the $2 \mathrm{~kg}$ skeletal weight. 


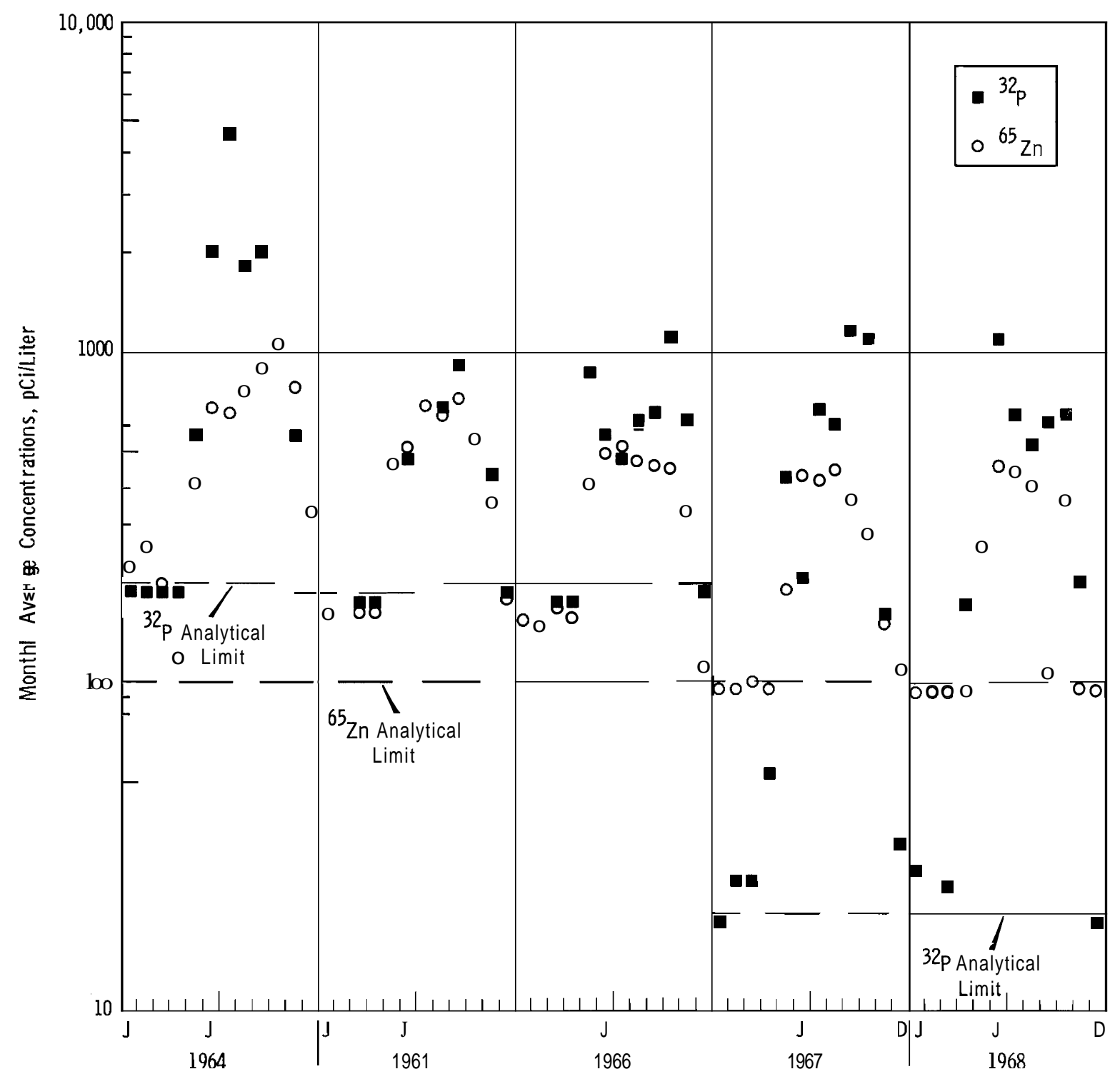

FIGURE 14. Monthly Average ${ }^{32} \mathrm{P}$ and ${ }^{65} \mathrm{Zn}$ Concentrations in Milk from River-Irrigated Farms (pCi/liter) 


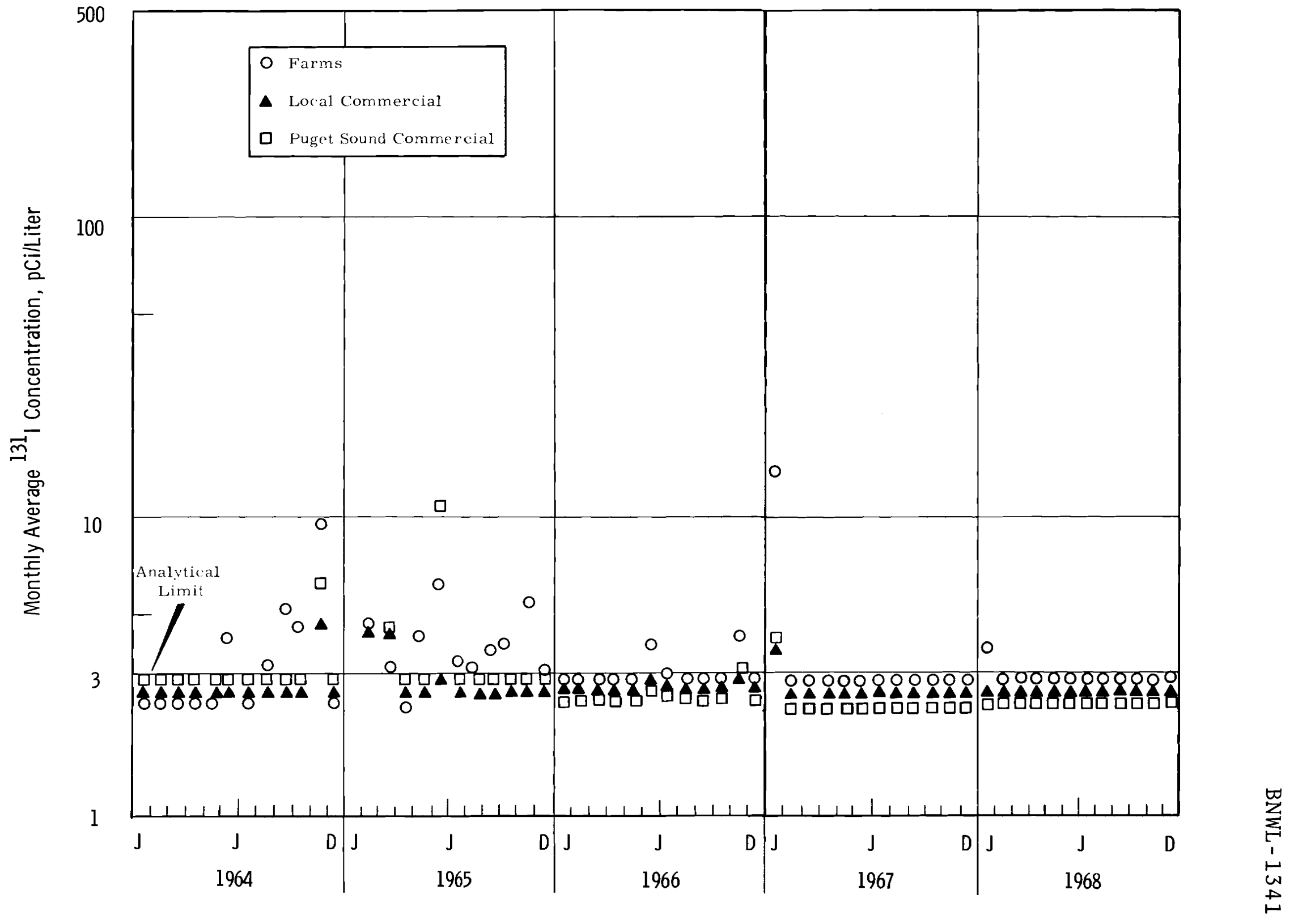

FIGURE 15. Monthly Average ${ }^{131}$ I Concentrations in Locally Available Milk (pCi/1) 
Miscellaneous fresh produce from local farms was sampled periodically for radioanalysis during the 1967 growing season. Results of these measurements, tabulated in the Appendices(2) were similar to those of previous years and indicated that only small quantities of radionuclides are present in locally grown produce.

Specifically, the concentrations of ${ }^{131}$ I found in samples of fresh leafy vegetables collected from local farms and markets during the period of May through September were less than or approximately equal to the analytical 1 imit of $0.05 \mathrm{pCi} / \mathrm{g}$. Based on an assumed average concentration of one-half the analytical $1 \mathrm{imit}$ and the consumption of $100 \mathrm{~g} /$ day throughout the year, the annual intake from this source would have been about $380 \mathrm{pCi}{ }^{131} \mathrm{I}$. Such an intake would imply an annual dose of about 0.6 mrem to the thyroid of an adult. Consumption of $50 \mathrm{~g} /$ day of the same vegetables by a small child would imply an annual dose of about 4 mrem to a 2 g thyroid.

EXTERNAL RADIATION

Ionization chambers (Victoreen stray radiation chambers) stationed on the Hanford reservation and in Richland measure the gamma radiation exposure from external sources (Figure 16 and the Appendices). (2) Measurements in air $1 \mathrm{~m}$ above ground level during 1968 averaged about $0.36 \mathrm{mR} /$ day or $130 \mathrm{mR} / \mathrm{yr}$ at Hanford and $0.28 \mathrm{mR} /$ day or $100 \mathrm{mR} / \mathrm{yr}$ at Richland. These were not significantly different from 1966 or 1967 values. Essentially all of the exposure at Richland is from natural background and worldwide fallout from nuclear testing.

Estimates of the external radiation dose received from recreational use of the Columbia River in the vicinity of the Hanford project is made from routine measurements at the river shoreline and below the surface of the river. The shoreline measurements are made with a large (40 liter) ionization chamber 


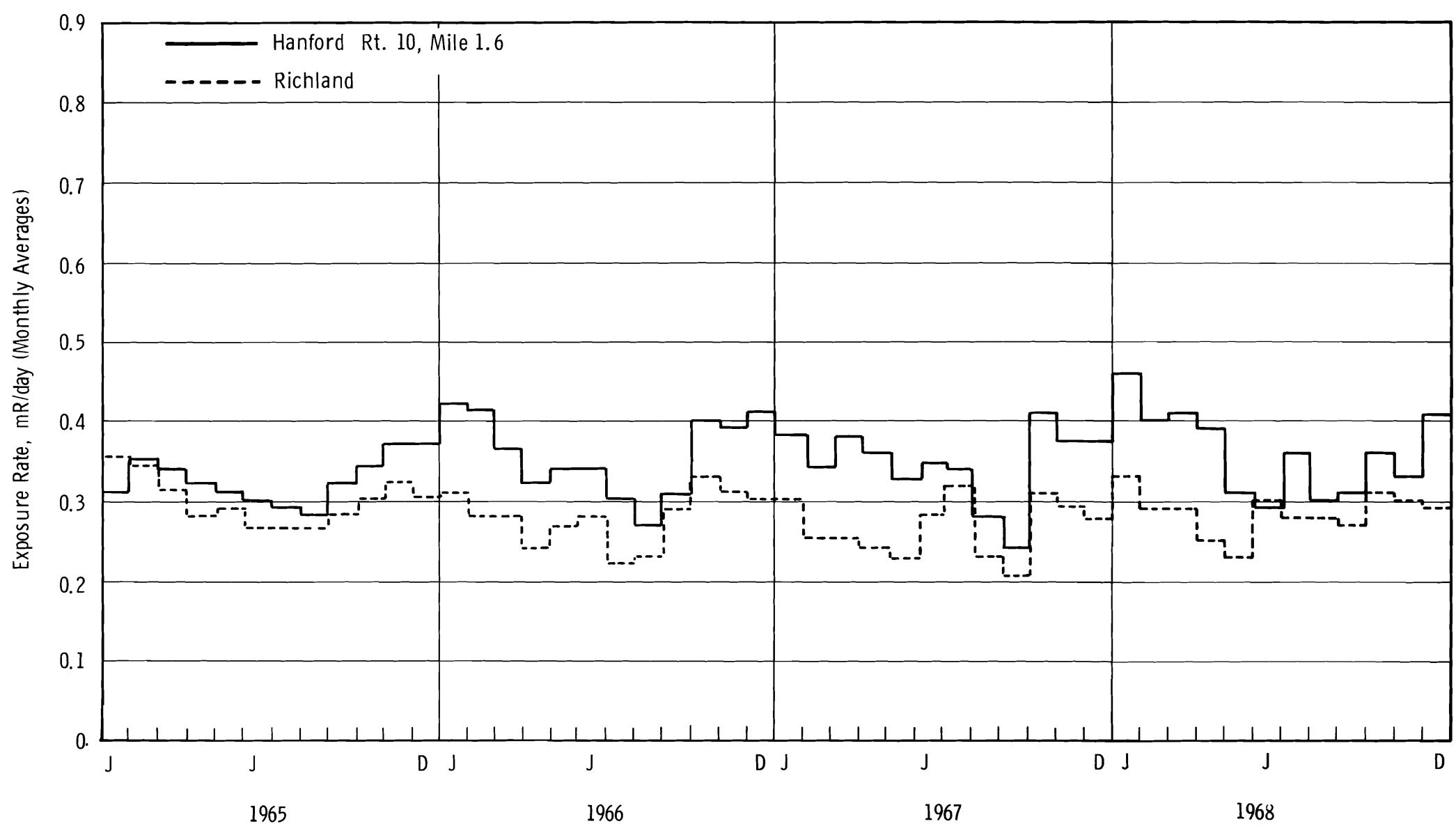

FIGURE 16. Monthly Average Gamma Exposure Rates at Hanford Test Location and at Richland (mR/day) 
centered at $1 \mathrm{~m}$ ( $3 \mathrm{ft}$ ) above the ground to approximate the dose to the gonads. Figure 17 shows monthly averages of the data for 1966, 1967, and 1968 at Richland and at Sacajawea Park, where the Snake River enters the Columbia.

The measured radiation includes components from radioactivity accumulated in sediment deposits and algal growths on the substrate at the river's edge. Gamma spectra show that ${ }^{46} \mathrm{Sc}$ and ${ }^{65} \mathrm{Zn}$ were the major contributors to the shoreline component, and ${ }^{24} \mathrm{Na}$ to the water component during 1968. The external exposure rate to swimmers, water skiers, and fishermen using the Columbia River in the Tri-Cities areas is predominately due to gamma rays of the order of $1 \mathrm{MeV}$ or greater. (38) The shoreline radiation levels are affected by both the daily and seasonal fluctuations in the flow rate and river level. Also apparent in Figure 17 is the effect of the extended reactor outage of 1966.

The primary fishing locations for the panfish species consumed in the largest quantities are downstream from Richland and the average dose rate for such fishermen is determined best from measurements at Sacajawea Park. During 1968, the average exposure rate at Sacajawea Park was $0.65 \mathrm{mR} /$ day $(27 \mu \mathrm{R} / \mathrm{hr})$ with an estimated $0.19 \mathrm{mR} /$ day $(8 \mu \mathrm{R} / \mathrm{hr})$ due to natural background radiation. An avid fisherman standing on the river shoreline at Sacajawea Park for as much as $500 \mathrm{hr}$ during the year would have had a gonad and torso exposure to gamma radiation of about $10 \mathrm{mR}$, (2\% of standard for whole body) not including natural background radiation.

Direct radiation measurements also are made in the Columbia River at several locations with clusters of five pocket-type ionization chambers positioned about 1 meter ( $3 \mathrm{ft}$ ) above the river bottom. Exposure rates are primarily due to the gamma emitters (especially ${ }^{24} \mathrm{Na}$ ) introduced into the river with 


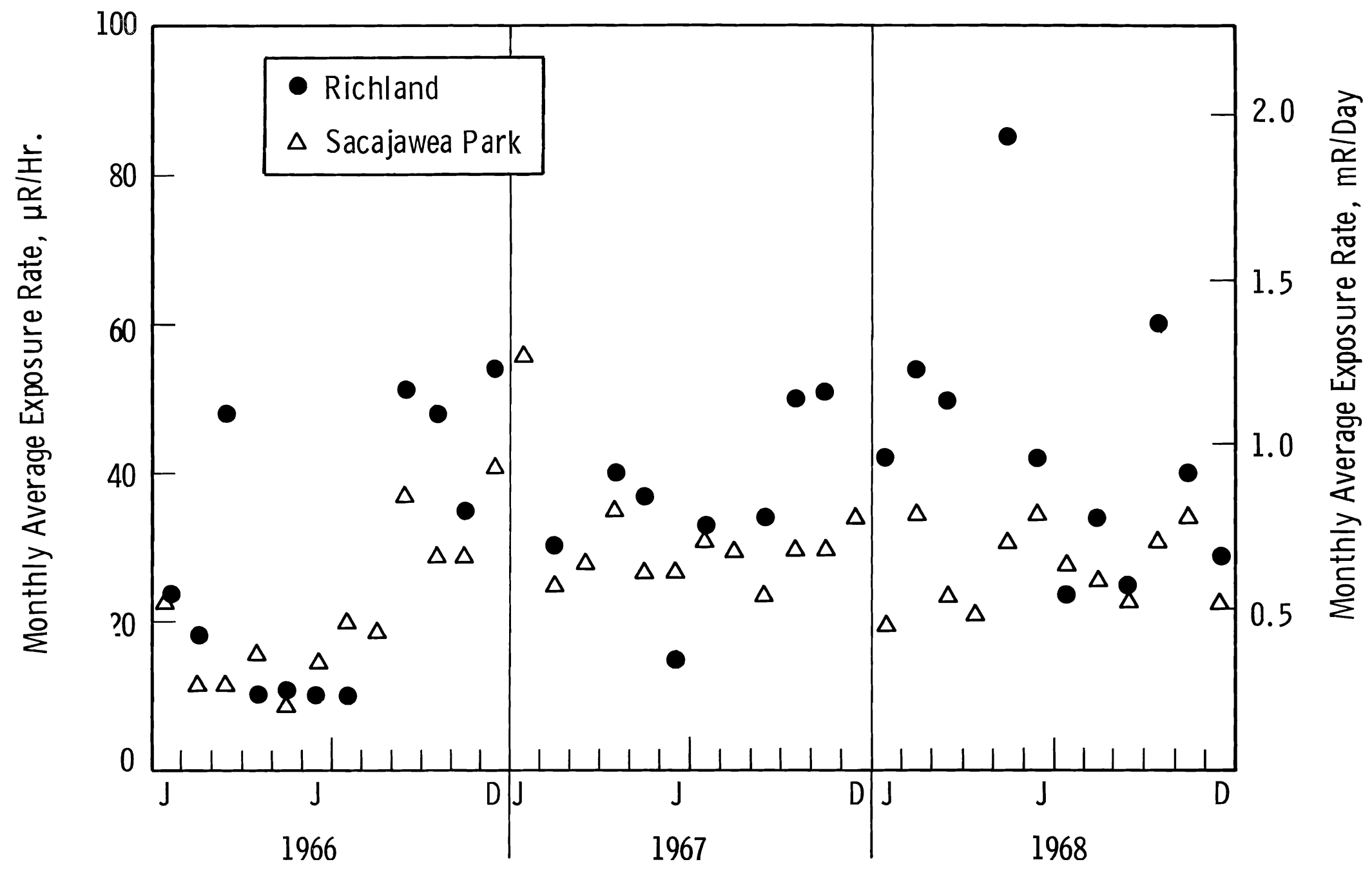

FIGURE 17. Monthly Average External Gamma Exposure Rates at the Columbia River Shoreline at Richland and Sacajawea Park 
reactor cooling water. In the vicinity of Richland, the average exposure rate in the water from April through October of 1968 was about $1.5 \mathrm{mR} /$ day.

During 1967, the whole-body dose received by the Average Richland Resident from recreational use of the Columbia River was based on an estimated $24 \mathrm{hr}$ immersion exposure time and was about 2 mrem. During 1968 a slightly different approach was used.

Teenagers were considered to be the major recreational users of the river. A recent survey of 430 Richland teenagers indicated an average exposure time for this group of about $115 \mathrm{hr}$ of which about one-third of the time was probably immersion and about two-thirds was shoreline exposure. (39)

Using the annual shoreline exposure rates at Richland of $0.91 \mathrm{mR} / \mathrm{day}$ or $0.038 \mathrm{mR} / \mathrm{hr}$ (not including background radiation) and the April-October average immersion exposure rate of $1.5 \mathrm{mR} /$ day or $0.062 \mathrm{mR} / \mathrm{hr}$, the average exposure to the teenage population was estimated to be about $5 \mathrm{mR}$ during 1968.

Some teenagers reported considerably greater time than the average. The 38 teenagers reporting greater than $300 \mathrm{hr} / \mathrm{yr}$ total of Columbia River recreation time were taken to be a representative sample of the critical population group for this exposure pathway. The estimated annual whole-body doses for individual members of this group ranged from 6 to 37 mrem with an average of about 17 mrem compared to the appropriate standard (500 mrem/yr). This represents iess than $4 \%$ of the standard.

The average whole-body dose received by the Richland population from recreational use of the Columbia River can be estimated by assuming that other age groups use the river less than teenagers, but with the same proportion of immersion and shoreline exposure times. Based on $11 \mathrm{hr}$ of immersion and $21 \mathrm{hr}$ of 
shoreline exposure in the vicinity of Richland, this whole-body dose during 1968 was estimated to be about 2 mrem, less than $1 \%$ of the appropriate standard of $170 \mathrm{mrem} / \mathrm{yr}$.

For comparison, if the recreational dose received by Richland residents were estimated for 1968 by the methods used in previous reports, the resulting whole-body dose would also be about 2 mrem.

\section{FALLOUT FROM NUCLEAR WEAPONS TESTS}

Dose increments received by residents of the Hanford environs from the fallout nuclides ${ }^{3} \mathrm{H},{ }^{90} \mathrm{Sr}$, and ${ }^{137} \mathrm{Cs}$ have been estimated routinely, although they are not included in the assessment of dose due to Hanford operations. Locally, this increment is below the national average because of the low rainfall. Measurements of fallout, like measurements of natural background radiation, help to put the radiation doses resulting from Hanford operations in proper perspective.

During the early influx of fresh fallout in 1968 following a foreign weapons test in December 1967, the peak ${ }^{131}$ I concentration in milk was $25 \mathrm{pCi} /$ iter compared to $83 \mathrm{pCi} / 1 \mathrm{t}$ er in January 1967, following a foreign weapons test of December 1966.

Estimates of ${ }^{3} \mathrm{H}$ intakes from drinking water were based on concentrations measured in river water (see page 33). Figure 18 shows concentrations of ${ }^{90} \mathrm{Sr}$ in locally available milk. These values are similar to concentrations found in commercial milk produced in other areas of low rainfall remote from the Hanford plant. ${ }^{90} \mathrm{Sr}$ in locally available milk averaged slightly above 4 pCi/liter during 1968, and slightly below that in 1967 . Concentrations of ${ }^{137} \mathrm{Cs}$ in locally available milk (Figure 19) were generally near the analytical $1 \mathrm{imit}$ of $30 \mathrm{pCi}{ }^{137} \mathrm{Cs} / 1$ iter during both 1968 and 1967. Worldwide fallout is the source of ${ }^{90} \mathrm{Sr}$ and ${ }^{137}$ Cs in milk. 


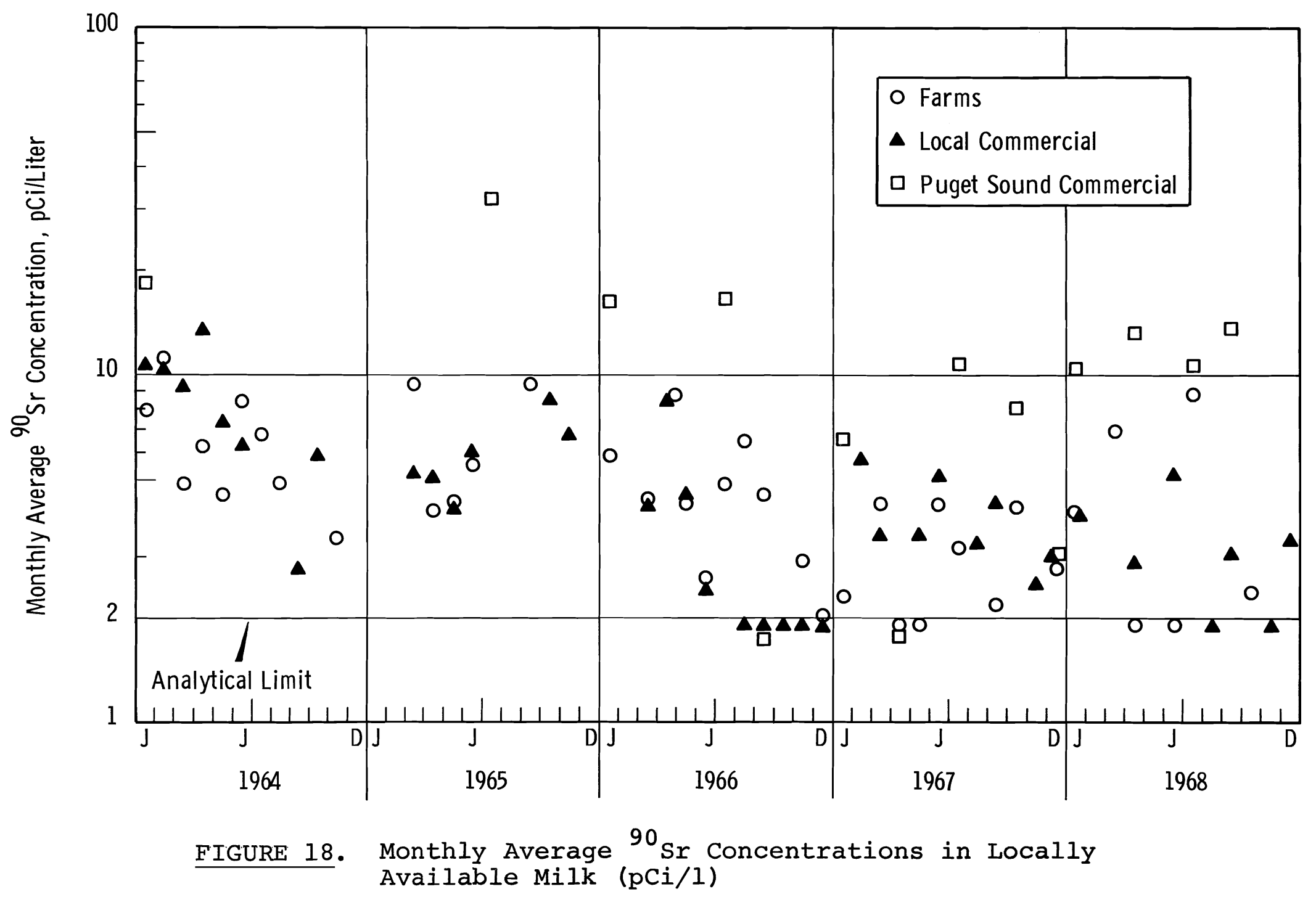




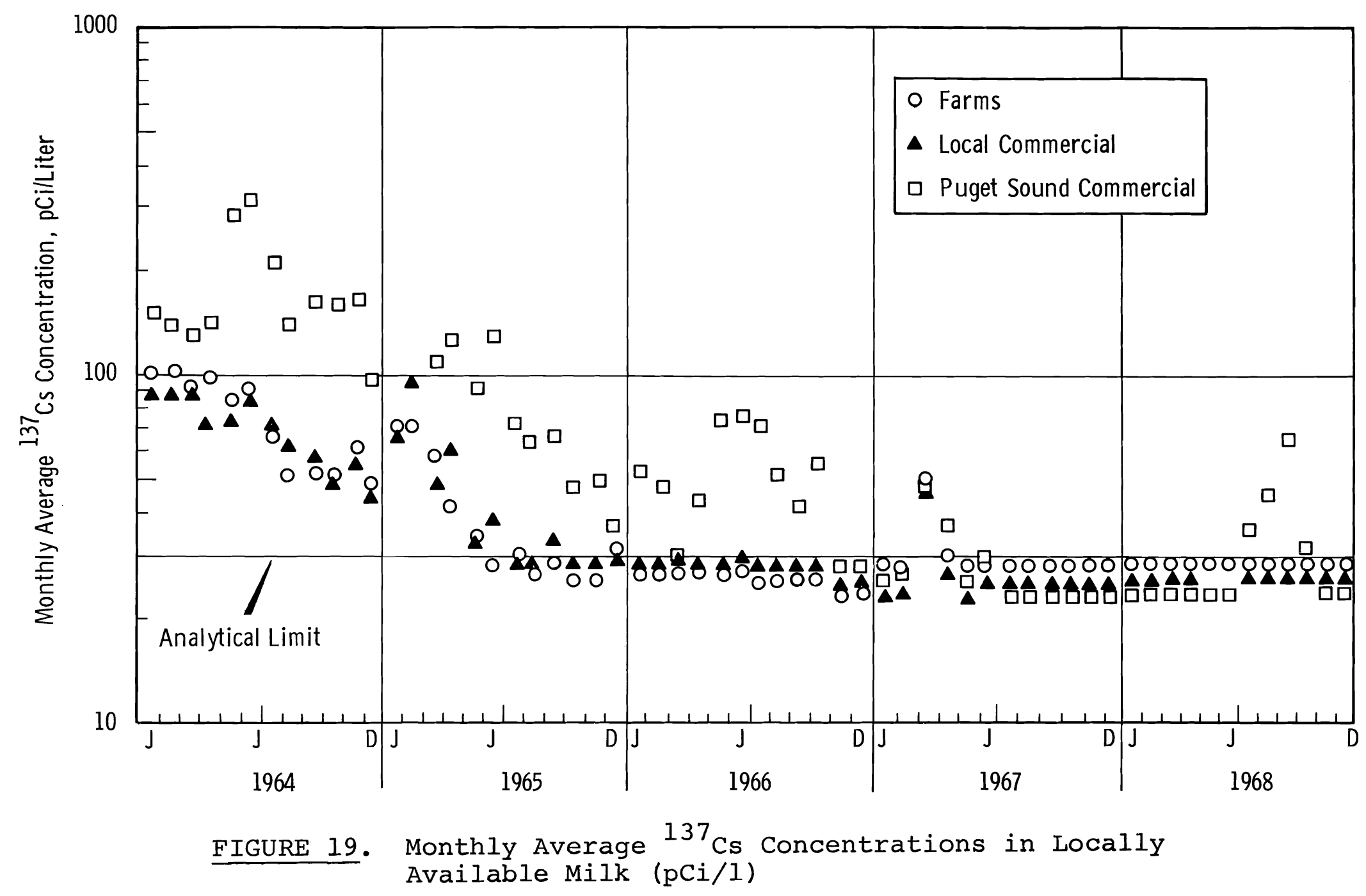


With the use of the assumption(40) that $40 \%$ of the total $9^{9} \mathrm{Sr}$ intake from fallout is obtained from milk, the daily intake of ${ }^{90} \mathrm{Sr}$ during 1968 was about 10 pCi/day for the Maximum Individual, 10 pCi/day for the Typical Richland Resident, and 5 pCi/day for the Average Richland Resident (adult). These values are similar to the intakes estimated for 1967 (8,9, and $5 \mathrm{pCi} / \mathrm{day}$, respectively). The total intake of ${ }^{137} \mathrm{Cs}$ during 1968 was about $0.06 \mu \mathrm{Ci}$ for the Maximum Individual, $0.01 \mu \mathrm{Ci}$ for the Typical Richland Resident, and $0.01 \mu \mathrm{Ci}$ for the Average Adult Richland Resident. These intakes are also similar to those for 1967.

Table 14 shows a summary of the estimated annual doses from fallout nuclides present in the Hanford environs. The ${ }^{90}$ Sr intakes are also evaluated in terms of the Federal Radiation Council guides. (23)

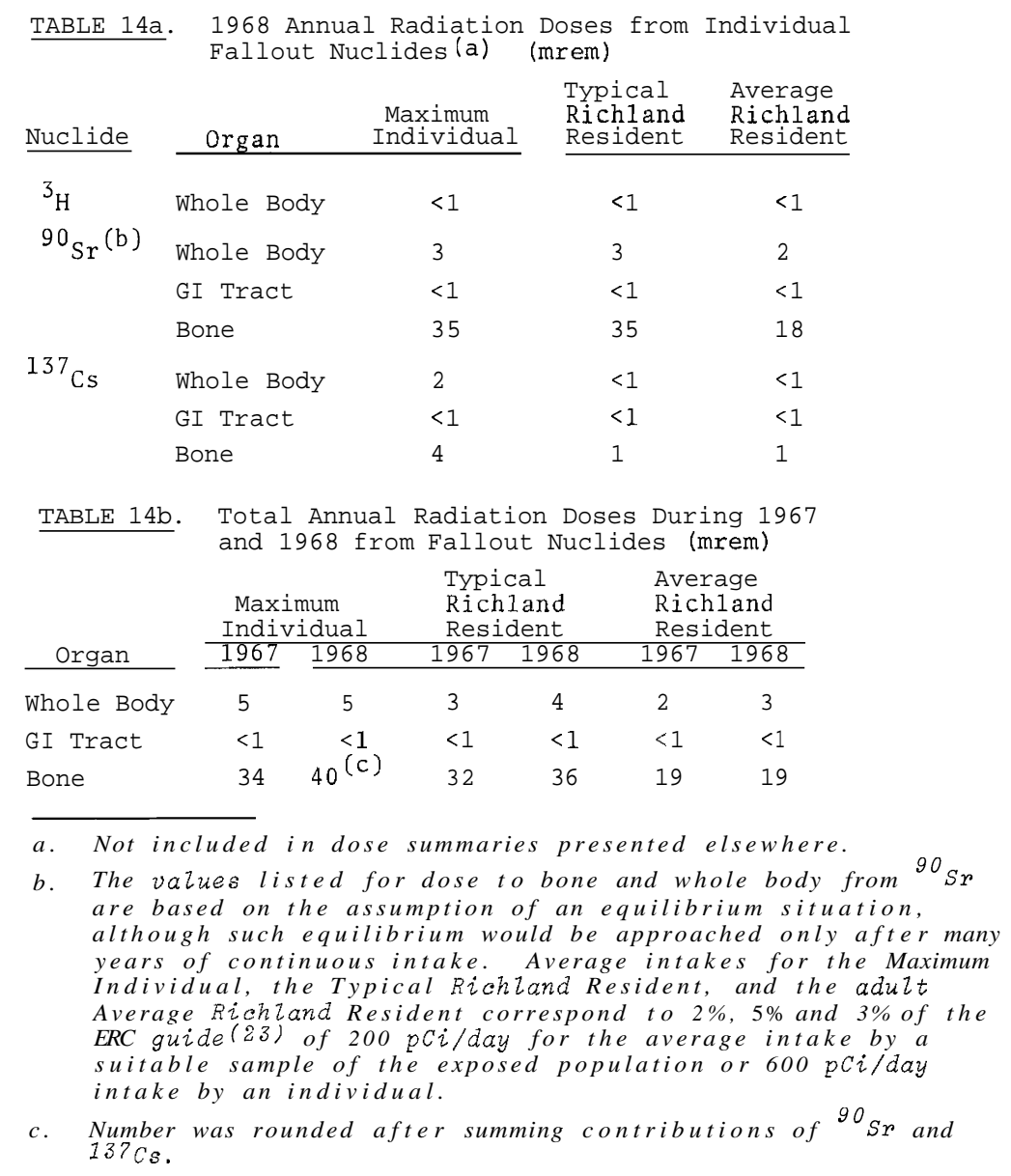


BNWL -1341

\section{COMPOSITE ESTIMATES OF RADIATION DOSE}

\section{THE MAXIMUM INDIVIDUAL}

Experience accumulated from the environmental surveillance program and associated research studies indicates that those individuals receiving the greatest percentage of permissible radiation dose from Hanford sources consume some combination of the following: fish caught locally in the Columbia River; game birds shot near the river; foodstuffs produced on local farms irrigated with Columbia River water drawn from below the reactors; and municipal water with the Columbia River as the source. A hypothetical Maximum Individual has been assigned assumed dietary habits (Table 15) which are identical to those used in the 1966 and 1967 Annual Reports $(18,3)$ and have been documented separately in detail. $(6,7)$

The consumption rates of most foods for this hypothetical Maximum Individual were compiled from intake rates described in published dietary surveys. The postulated sources include water from the Pasco municiple system (Radionuclides in Drinking Water, page 34) and milk, meat, and produce from riverirrigated farms in the Riverview district (Radionuclides in Milk and Produce, page 43). The consumption of 200 meals/yr of panfish taken from the Columbia River (Radionuclides in Columbia River Fish, page 37) is based on the maximum reported in local surveys. A total of $500 \mathrm{hr} / \mathrm{yr}$ along the riverbank (External Radiation, page 49) to catch these fish is also assumed.

The composite dose for this Maximum Individual is summarized in Table 16 and illustrated in Figure 20. The estimated dose to the GI tract for the Maximum Individual during 1968 was about 62 mrem or about $4 \%$ of the appropriate standard, which is slightly lower than the 1967 GI tract dose which was about 5\% of the standard. The whole-body dose estimate for 1968, 24 mrem 
BNWL- 1341

TABLE 15. Dietary Assumptions

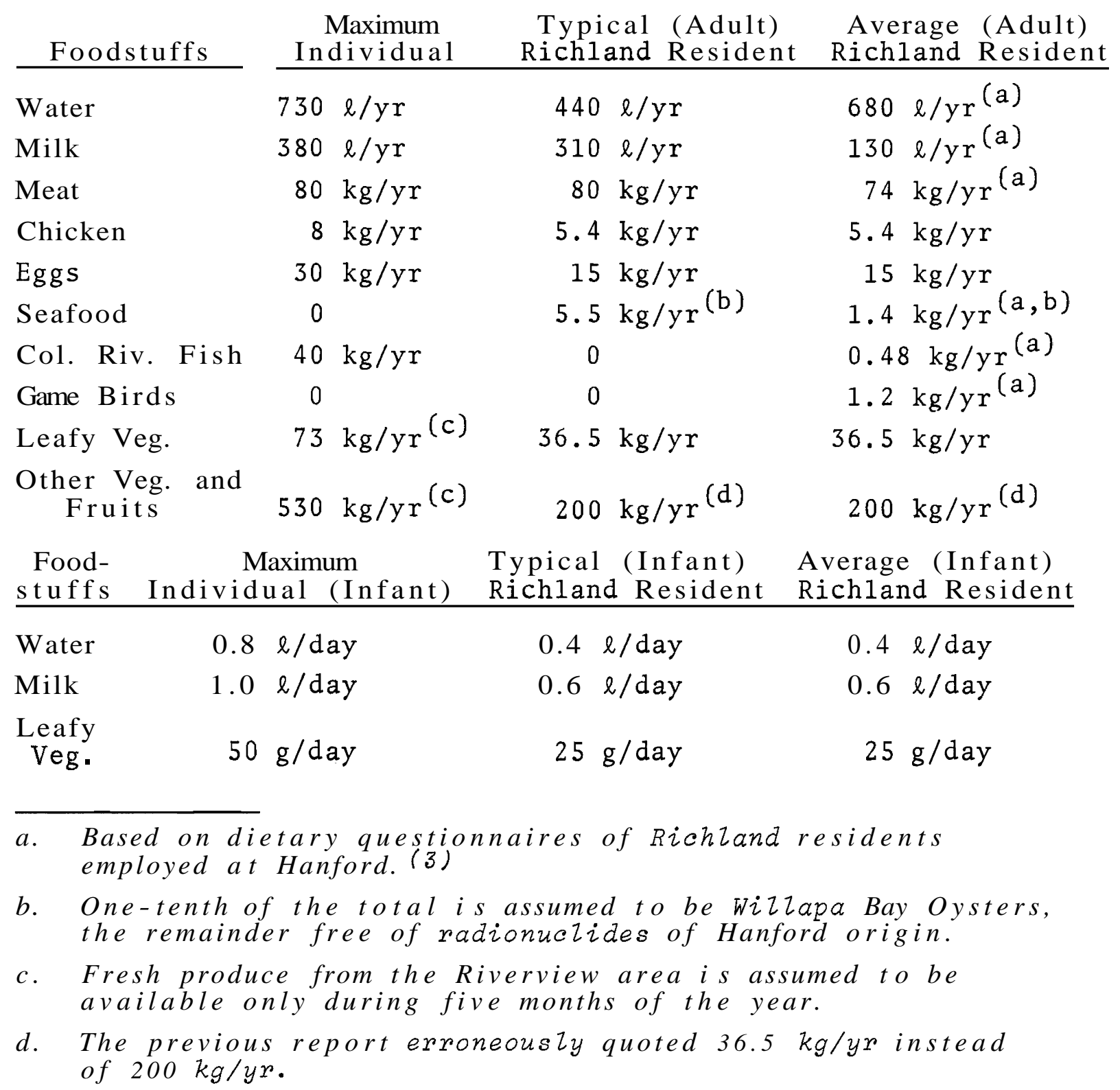


TABLE 16. (a) Summary of Radiation Doses ${ }^{(b)}$ in the Hanford Environs, 1968

Organ

Annual Dose, Standard, mrem mrem

$\%$ of

Maximum Individual

Bone

Whole-Body

250

1500

17

24

500

5

GI Tract

Thyroid (infant)

62

1500

4

110

1500

7

Typical Richland Resident

Bone

Whole-Body

GI Tract

Thyroid (infant)

Average Richland Resident

Bone

Whole-Body

GI Tract

Thyroid (infant)

$\begin{array}{rrr}8 & 500 & 2 \\ 3 & 170 & 2 \\ 24 & 500 & 5 \\ 55 & 500 & 11\end{array}$

$13 \quad 500 \quad 3$

$3 \quad 170 \quad 2$

$25 \quad 500 \quad 5$

$\begin{array}{lll}39 & 500 & 8\end{array}$

a. Identical to Table I presented in the Summary Section of this report.

b. Doses from fazzout and naturaz background not included. 
BNWL-1341
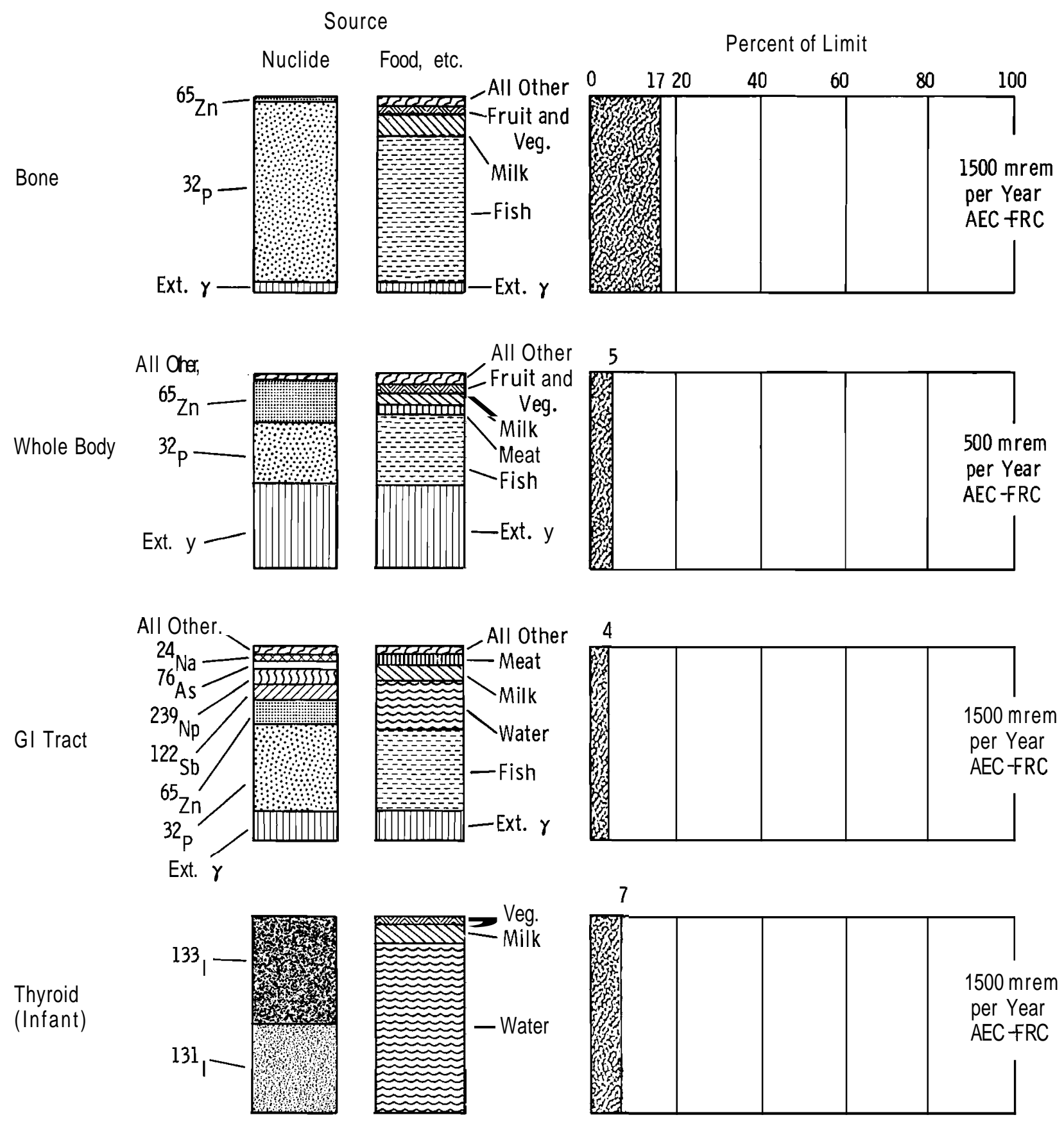

FIGURE 20. Estimated Doses to the Maximum Individual-1968 
BNWL -1341

or about 5\% of the appropriate standard, was somewhat lower than the 1967 estimate of 32 mrem (6\% of standard). The estimated percent of the Maximum Permissible Rate of Intake (for ingested radionuclides) with bone as the critical organ was $9 \%$ during 1968, compared to 12\% during 1967 and 10\% during 1966. However, for purposes of this report, an estimated bone dose of 250 mrem (17\% of the appropriate standard) was derived from radionuclide intake and included a contribution from external radiation.

In the case of the thyroid gland, the highest radiation doses are those received by infants because of the relatively small thyroid mass (assumed to be 2 g). The Maximum Individual (infant) is defined as a Richland infant drinking Richland water with radionuclide concentrations equal to those at the water plant and consuming food and milk obtained from commercial sources. Dietary assumptions for 1968 (Table 14) were identical to those used in 1967.

The estimated thyroid dose received by such a Richland infant in 1968 was 110 mrem (7\% of the appropriate standard) which is somewhat greater than the maximum infant thyroid dose for 1967 (97 mrem or 6\% of the standard).

The slight increase resulted from an increase in the estimated dose contribution from ${ }^{133} \mathrm{I}$ in drinking water in 1968. Measurements of grab samples of drinking water taken monthly at the Richland water plant during 1968 indicated a somewhat higher ratio of concentrations of ${ }^{133} \mathrm{I}$ to ${ }^{131} \mathrm{I}(6: 1)$ than had been assumed for 1967 (4:1). The annual average ${ }^{13} 1_{I}$ concentration in cumulative samples multiplied by the ${ }^{133}$ I to ${ }^{131}$ I ratio was the estimated average ${ }^{133}$ I concentration. Based on the 1968 values, the ${ }^{133} \mathrm{I}$ in drinking water contributed 58\% of the Maximum Individual (infant) thyroid dose. 
For comparison with the maximum Richland infant, the thyroid dose estimated for a Riverview infant consuming foods from the same sources as the adult Maximum Individual was 79 mrem in 1968. This lower value reflects the lesser contribution of ${ }^{133}$ I in Pasco water compared to Richland water.

Table 17 shows the trend of Maximum Individual dose estimates for the period 1964-1968. The 1968 thyroid dose and bone doses have been adjusted to a comparable basis (from ${ }^{131}$ only). The increase observed in the thyroid dose during 1966 reflects an unusual release of radioiodine to the Columbia River from a production reactor. (18) The long-term trend for whole-body and GI-tract doses is obviously downward. Bone doses for the Maximum Individual are heavily dependent upon ${ }^{32} \mathrm{P}$ in Columbia River fish which are, in turn, dependent on river conditions as well as radionuclide release rates. The lower 1966 estimate compared to 1965 and 1967 reflects to some extent the extended reactor outage of that year. The decreases to $9 \%$ MPRI in 1968 resulted primarily from decreased concentrations of ${ }^{32} \mathrm{P}$ in Columbia River fish.

TABLE 17. Dose Estimates (a) for Maximum Individual, 1964 to 1968 (\% of standard except for bone)

G I Tract

Whole-Body

Bone

Thyroid (infant)

\begin{tabular}{cccccc}
1964 & 1965 & 1966 & 1967 & 1968 & $\begin{array}{c}\text { Standard, } \\
\mathrm{mrem}\end{array}$ \\
\hline 9 & 6 & 5 & 5 & 4 & 1500 \\
18 & 8 & 7 & 6 & 5 & 500 \\
$23 \%$ MPRI & $12 \%$ MPRI & $10 \%$ MPRI & $12 \%$ MPRI & $9 \%$ MPRI (c) & -- \\
5 & 4 & 6 & $3(b)$ & $3(b)$ & 1500
\end{tabular}

a. Does not include falzout and natural background.

b. For comparison, includes dose from ${ }^{131}$ I only.

c. For comparison, expressed as \% MPRI of ingested radionuclides rather than as percent of standard including dose from external sources. See Standards for Evaluation, page 5, for further explanation. 
BNWL -1341

\section{THE TYPICAL RICHLAND RESIDENT}

The majority of people who live in Richland obtain their food from local commercial stores (rather than from farms), and consume little or no Columbia River fish or local game birds. The principal source of radionuclides of Hanford origin ingested by such people is drinking water obtained from the Columbia River. For continuity with previous years, the doses for several organs of the body for the Typical Richland Resident have been calculated for 1968. Table 15 shows the dietary assumptions for this group.

The estimated dose to the GI tract of the Typical Richland Resident from nuclides of Hanford origin during 1968 was about 24 mrem or $5 \%$ of the maximum permissible dose, the same as in 1967. Ninety percent of the GI tract dose was contributed by drinking water. The combined doses from intake of bone-seeking nuclides and external exposure was 8 mrem or about $2 \%$ of the appropriate standard (500 mrem) for a suitable sample of the exposed population. Similar radionuclide intakes corresponding to about 1\%MPRI were observed for 1966, 1967, and 1968. The estimated whole-body dose of the Typical Richland Resident for 1968 was 3 mrem or $2 \%$ of the appropriate standards, slightly less than for 1967.

For comparison, whole-body doses from natural background (excluded from the FRC guide) and from fallout in this region are estimated for the Typical Richland Resident at about 100 and $4 \mathrm{mrem} / \mathrm{yr}$, respectively.

For dose to the thyroid, the most appropriate sample of the exposed population would seem to be Richland infants. Table 15 lists the assumed consumption rates. The water is from the municipal system (assuming radionuclide concentrations equal to those at the water plant), the milk is from commercial sources, and a few leafy vegetables in season are obtained from local markets. From these sources, a thyroid dose for the Typical 
Richland Resident (infant) was 55 mrem, or about $11 \%$ of the appropriate standard, including an estimated contribution of 31 mrem from ${ }^{133}$ I in the drinking water. For comparison, the calculated thyroid dose for 1967 from the same sources was 27 mrem for ${ }^{131_{I}}$ only.

Figure 21 shows the source and nuclide contributions to the doses to various organs for the'Typical Richland Resident and Table 14 presents a dose summary.

THE AVERAGE RICHLAND RESIDENT

Estimates of average consumption rates of several food items were obtained for Richland adults from analysis of dietary questionnaires completed by plant employees. The program and the data have been discussed ${ }^{(3)}$ in another report. The principal changes from the consumption values assumed for the Typical Richland Resident were an increase of $55 \%$ for tap water (of which a substantial portion was consumed as coffee), a decrease of $58 \%$ for milk, a $75 \%$ decrease for seafood (one-tenth of which is still assumed to be Willapa Bay oysters), and the inclusion of $0.48 \mathrm{~kg} / \mathrm{yr}$ of Columbia River $\mathrm{fish}$ and $1.24 \mathrm{~kg} / \mathrm{yr}$ of game birds. Table 15 includes a summary of the Average Richland Resident's diet.

In computing doses for the Average Richland Resident, the assumed food sources were Richland drinking water with average concentrations adjusted for decay and dilution (Radionuclides in Drinking Water, page 34), Columbia River fish with the average species composition of fish ingested by the Maximum Individual (Radionuclides in Columbia River Fish, page 37), "average game birds" (Radionuclides in Game Birds, page 40), and milk, meat, and produce from local stores (Radionuclides in Milk and Produce, page 43). 
BNWL - 1341
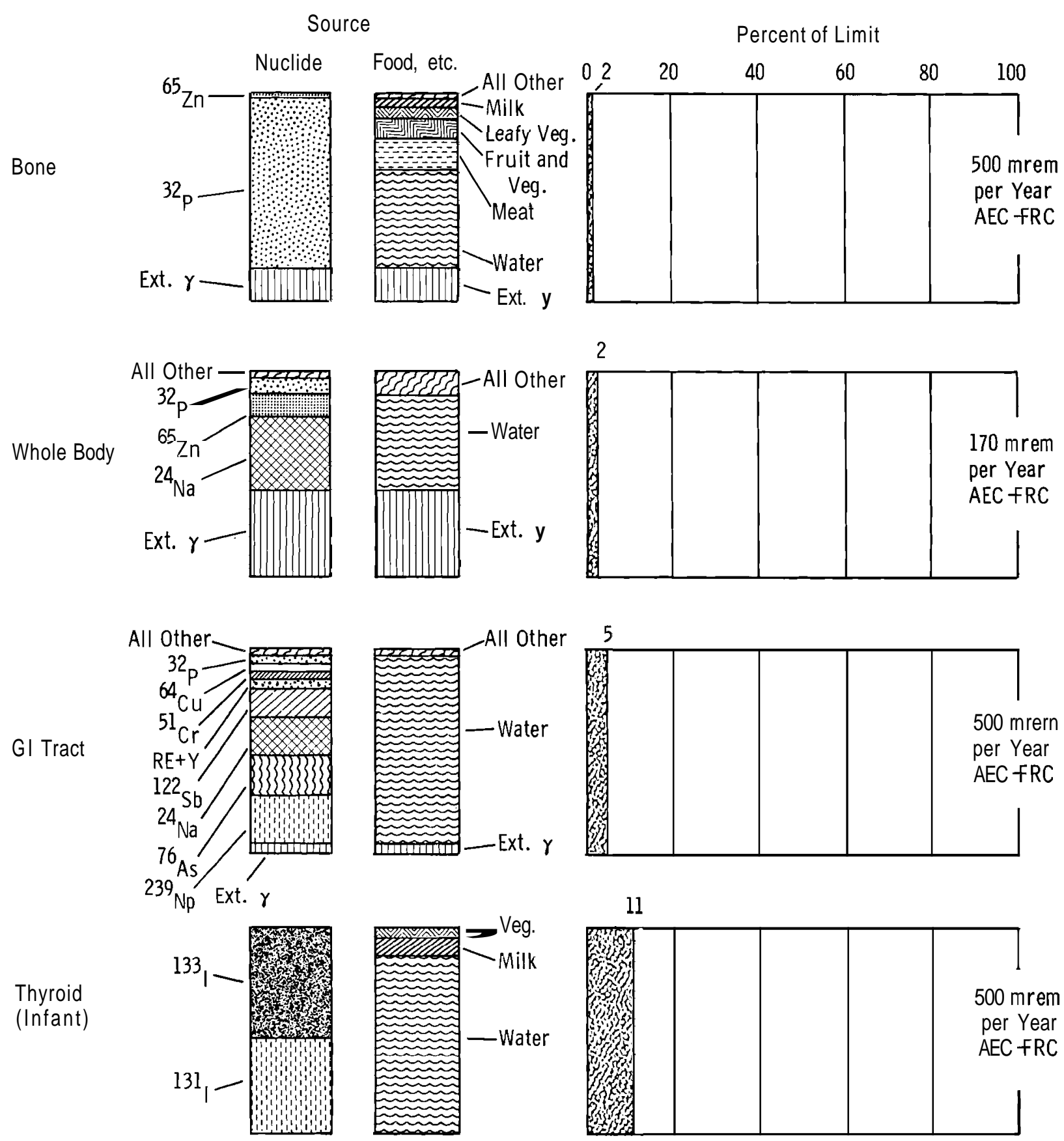

FIGURE 21. Estimated Doses to the Typical Richland Resident-1968 
Because no significant contribution from Hanford operations to the background radiation levels in Richland can be discerned, the external dose to the adult Average Richland Resident is assumed to result only from recreational use of the Columbia River. An estimated dose increment slightly less than $2 \mathrm{mR}$ from immersion in the river and activities along the shoreline was included in the GI tract, whole-body, and bone doses on the basis of a recent survey of Richland teenagers and extrapolation of these data to the entire population.

The organ of the adult Average Richland Resident that received the highest percentage of the appropriate dose standard during 1968 was the GI tract at $25 \mathrm{mrem}$ or 5\% of the standard. The principal source (93\% of the total dose) was drinking water. The whole-body dose from Hanford nuclides during 1968 was estimated to be about 3 mrem (2\% of the standard), $46 \%$ of which resulted from recreational use of the Columbia River.) The dose to bone was 13 mrem or about 3\% of standard in 1968 including a dose from ingested radionuclides corresponding to about $1 \%$ MPRI in the terminology of past reports. About $41 \%$ of the total bone dose was derived from drinking water, 18\% from fish, 13\% from external radiation, $11 \%$ from meat, 8\% from game birds, with 9\% from remaining food items. A single radionuclide $\left({ }^{32} \mathrm{P}\right)$ accounted for $85 \%$ of the total bone dose. Dose estimates for the Average Richland Resident are illustrated in Figure 22 and summarized in Table 16.

As in the past report, the infant Average Richland Resident was assumed to have the same food intakes and sources as were used for the infant Typical Richland Resident. However, use of an average composition of drinking water (adjusted for radioactive decay and dilution) resulted in a lower thyroid dose of 39 mrem or about $8 \%$ of the standard. 
BNWL -1341
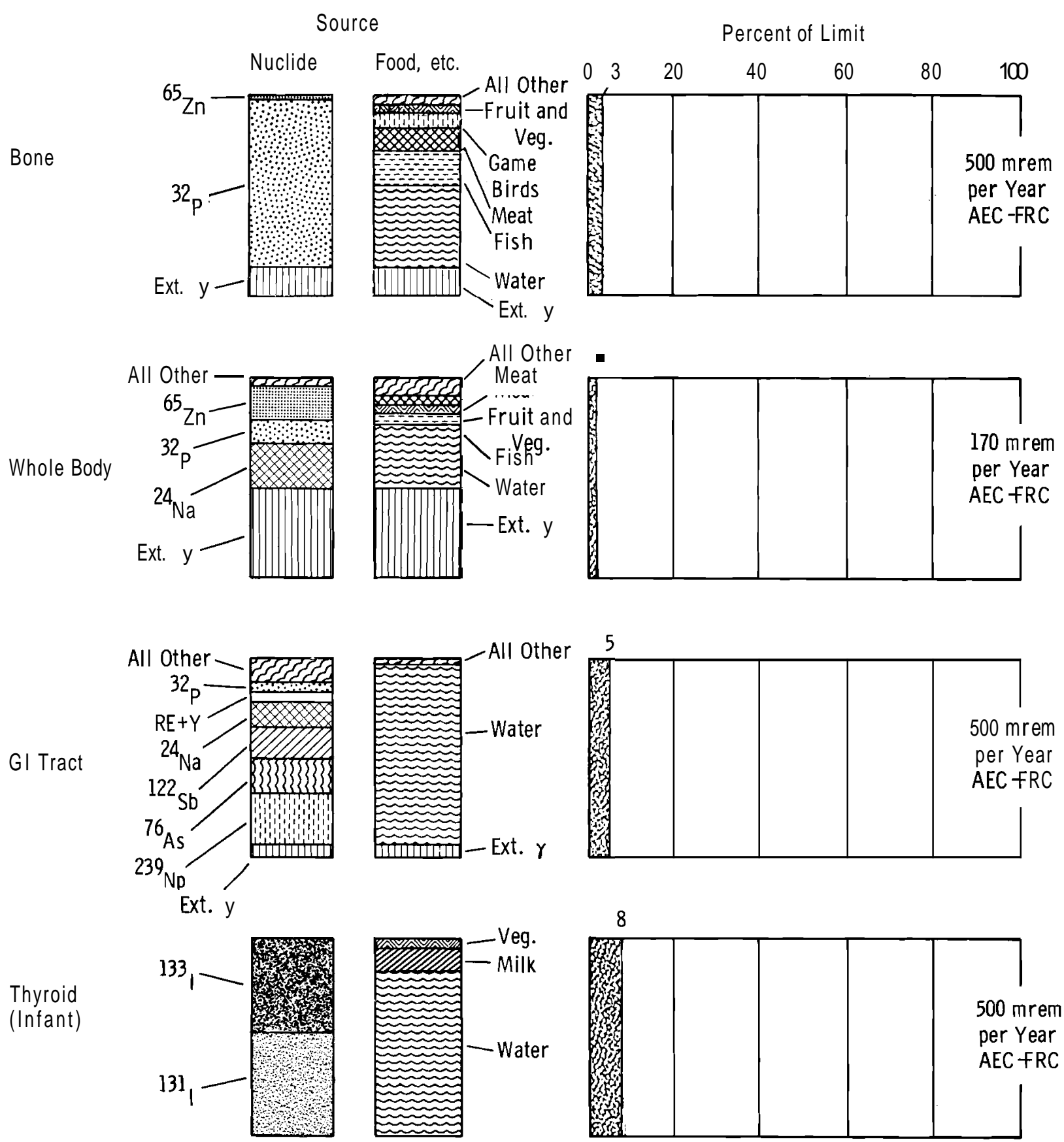

FIGURE 22. Estimated Doses to the Average Richland Resident-1968 
BNWL- 1341

\section{ACKNOWLEDGMENTS}

The radiochemical data presented here and in the Appendices were supplied by the U.S. Testing Co., Inc., which performed a 11 routine radioassays of environmental samples.

The cooperation of many Battelle-Northwest staff members who collected samples, performed many tedious radioassays, prepared and provided data, and reviewed this document is gratefully acknowledged. Of special note were the efforts of W. C. Horton and his Environmental Monitoring group, J. K. Soldat who provided technical support, and J. P. Corley who was in charge of the environmental evaluations program during 1968.

The cooperation and contributions of the several city, state, and federal agencies listed below are also gratefully acknowledged.

Federal Aviation Agency

Walla Walla, Washington

Pendleton, Oregon

Kennewick Water Department

Kennewick, Washington

Pasco Water Department

Pasco, Washington

Richland Water District

Richland, Washington

U. S. Army Corps of Engineers

McNary, Oregon

Bonneville, Oregon

Washington State Department of Game

Olympia, Washington

Washington State Department of Highways

Ellensburg, Washington

Wenatchee, Washington

Washington State Patrol

Yakima, Washington 
Many samples supplied during the year by the following individuals in Washington state provided valuable information about the radiological status of the environs.

Oysters: Coast Oyster Company, South Bend

Milk and Pasture Grass: N. Atterberry, Benton City;

H. G. Bleazard, Eltopia; D. N. Dinneen, West Richland; W. F. Harris, Pasco; B. Harrison, Pasco; L. M. Monson, Eltopia; New Moon Dairy, Mesa; W. M. Nichols, West Richland; H. H. Olson, Pasco; A. W. Taylor, Pasco; H. L. Tedro, Pasco; Twin City Creamery, Kennewick. 
BNWL -1341

\section{REFERENCES}

1. "Waste Disposal," AEC Manual, Chapter RL-0510. U. S. Atomic Energy Commission, Richland Operations Office, Richland, Washington, Juzy 1967.

2. Evaluation of RadioZogicaZ Conditions in the Vicinity of Hanford for 1968 (Appendices), edited by C. B. Wilson, BNWL-1341 APP. BattelZe-Northwest, Richland, Washington, 1970 .

3. Evaluation of RadioZogicaZ Conditions in the Vicinity of Hanford for 1967, edited by C. B. Wooldridge, BNWL-983 and BNWL-983 APP (Appendices). Battelle-Northwest, Richland, Washington, March 1969.

4. "Reported Nuclear Detonations, December 1967," Radiological Health Data and Reports, vol. 9, no. 1, p. 62. January 1968.

5. "Environmental Radioactivity Folzowing Project Schooner," RadioZogicaZ Health Data and Reports, vol. 10, no. 4, pp. 171-175. April 1969.

6. R. H. Wilson and T. H. Essig. Criteria Used to Estimate Radiation Doses Received by Persons Living in the Vicinity of Hanford: Interim Report, BNWL-706. Battelle-Northwest, Richland, Washington, July 1968.

7. T. H. Essig and J. P. Corley. Criteria Used to Estimate Radiation Doses Received by Persons Living in the Vicinity of Hanford: Interim Report No. 2, BNWL-1019. BattelleNorthwest, Richland, Washington, April 1969.

8. "Permissible Levels of Radiation Exposure," AEC Manual, Chapter 0524. U.S. Atomic Energy Commission, Washington, D. C., 1963. Revised November 1968.

9. J. W. Healy, B. V. Andersen, H. V. Clukey, and J. K. Soldat. "Radiation Exposure to People $i$ n the Environs of a Major Production Atomic Energy PZant," Proceedings of the Second International Conference on the Peaceful Uses of Atomic Energy 18:309, United Nations, Geneva, 1958.

10. B. V. Andersen. Hanford Environmental Monitoring Annual Report - 1958, HW-61676. Available from Clearinghouse for Federal Scientific and Technical Information, Springfield, Virginia, 1959.

11. R. L. Junkins et al. Evaluation of RadioZogicaZ Conditions in the Hanford Environs for 1959, HW-64371. Available from Clearinghouse for Federal $S$ cientific and Technical Information, springfield, Virginia, 1960. 
Evaluation of RadioZogicaZ Conditions in the Vicinity of Hanford for 1960 through 1966. $H W^{\prime} s$ avaizable from Clearinghouse for Federal Scientific and Technical Information. Springfield, Virginia; BNW's, Battelle-Northwest, Richland, Washington:

12. Edited by I. C. NeZson, HW-68435. 1960.

13. Edited by I. C. Nelson, HW-71999. 1961.

14. Edited by R. H. Wilson, HW-76526. 1962.

15. Edited by R. H. Wilson, HW-80991. 2963.

16. Edited by R. H. Wizson, BNWL-90. 1964.

17. Edited by J. K. Soldat and T. H. Essig, BNWL-316, BNWL-316 APP. 1965.

18. Edited by J. K. Soldat and T. H. Essig, BNWL-439, BNWL-439 APP. 1966.

19. International Commission on RadioZogicaZ Protection. "Recommendations of the International Commission on RadioZogicaZ Protection (Revised Dec., 1954),"Brit. J. Radiology, Supplement 6, 1955.

20. International Commission on RadioZogicaZ Protection. "Report of ICRP Committee 11 on Permissible Dose for Internal Radiation (1959), with Bibliography for Biological, Mathematical, and Physical Data," Health Physics, vol. 3, no. 1, 1960.

21. International Commission on RadioZogicaZ Protection.

"Recommendations of the International Commission on Radiological Protection (As Amended 1959 and Adopted 1962)," ICRP Publication 6. Pergamon Press, New York, 1964.

22. "Background Materials for the Development of Radiation Protection Standards," Staff Report of the Federal Radiation Council. Report No. 1. May 1960.

23. "Background Materials for the Development of Radiation Protection Standards," Staff Report of the Federal Radiation Council. Report No. 2. September 1961.

24. "Estimates and Evaluation of FaZzout in the United States from Nuclear Weapons Besting Conducted Through 1962." Staff Report of the Federal Radiation Counciz. Report No. 4. May 1963.

25. "Maximum Permissible Body Burdens and Maximum Permissible Concentrations of Radionuclides in Air and $i n$ Water for Occupational Exposure," Nat. Bur. Std. Handbook 69,

pp. 1-95. Published by Superintendent of Documents, U.S. Government Printing office, Washington, D.C., June 5, 1959. 
26. J. K. SoZdat. Unpublished Bone Dose-Estimation Data. Battelze-Northwest, Richland, Washington.

27. "Weekly Runoff Reports - Pacific Northwest Water Resources (1968)", U.S. Department of the Interior, U.S.G. S., Northwest Water Resources Data Center, Portiand, Oregon. 1968.

28. J. K. SoZdat. "The Relationship Between ${ }^{131}$ I Concentrations in Various Environmental Samples," HeaZth Physics, vol. 9, p. 1167.1963.

29. D. H. Denham. Radiological Status of the Groundwater Beneath the Hanford Project - July-December, 1968, BNWL-1047. Battelze-Northwest, Richland, Washington.

30. "Reported Nuclear Detonations, December 1968," RadioZogicaZ HeaZth Data and Reports, vol. 10, no. 1, p. 45. January 1969.

31. J. K. SoZdat. UnpubZished Fisherman Survey Data. BatteZzeNorthwest, Richland, Washington. (Report in preparation.)

32. "AEC Opens Hanford Acres to Hunters," Hanford Project News, no. 16, vol. 5. August 9, 1969.

33. J. K. SoZdat. Unpublished Game Bird Data. BatteZZeNorthwest, Richland, Washington. (Report in preparation.)

34. A. H. Seymour and G. B. Lewis. Radionuclides of Columbia River Origin in Marine Organisms, Sediments, and Water Colzected from the Coastal and Off-Shore Waters of Washington and Oregon, 1961-1963, UWFL-86. University of Washington, Seattze, Washington, December 10, 1964.

35. National Shellfish Sanitation Program Manual of Operations, Publ. No. 33. Public HeaZth Service, Washington, D.C., 1965.

36. RadioZogicaZ Health Data and Reports, vol. 9, no. 1-12. U.S. Department of Health, Education, and Welfare, Pubiic HeaZth Service, Washington D. C.

37. Environmental Radiation Surveizzance Quarterly Data Reports - 1968. Washington State Department of HeaZth, Office of Air Quality Controz, ozympia, Washington.

38. D. H. Denham. Unpublished Shoreline Data. BattezzeNorthwest, Richland, Washington. 1969.

39. J. F. Honstead. Unpublished Recreational Use Data. Battelze-Northwest, Richland, Washington. 1969.

40. Summary of Avaizable Data on the Sr-90 Content of Foods and of Total Diets in the United States, AASL-90. U.S. Atomic Energy Commission, HeaZth and Safety Laboratory, August 1960. 
BNWL - 1341

\section{DISTRIBUTION}

No. of

Copies

\section{OFFSITE}

1 AEC Chicago Patent Group

G. H. Lee

1 AEC Division of Biology and Medicine

J. N. Wolfe

1 AEC Division of Compliance Region V 2111 Bancroft Way Berkeley, California 94707

H. E. Book

1 AEC Division of Reactor Development and Technology

W. G. Belter

267 AEC Division of Technical Information Extension

2 AEC Idaho Operations Office Health and Safety Division Idaho Falls, Idaho 83401

J. R. Horan

G. Voelz

AEC Library, Washington

Division of Operational Safety

M. B. Biles

G. M. Dunning

A. A. Schoen

Division of Production

G. B. Pleat

E. F. Greenleaf

Office of Public Information

F. J. Tobey (12)

1 AEC Nevada Operations Office Effects Evaluation Commission P. O. Box 14100 Las Vegas, Nevada 89114

J. J. Davis

1 Atomic Energy of Canada Limited Health Phvsics Branch

Toronto, Ontario, Canada

I. L. Ophel

1 Australian, A.E.C.R.E. Health Physics Research Lucas Heights Private Bag Southerland N.S.W. Australia
No. of

Copies

1 Colorado State University

Colorado Cooperative Wildlife Research Unit

Fort Collins, Colorado 80521

F. A. Glover

1 du Pont Company, Aiken (AEC)

Aiken, South Carolina 29801

W. C. Reinig

5 Federal Water Pollution Control Administration 570 Pittock Block Portland, Oregon 97205

J. L. Agee

1 Federal Water Pollution Control Administration Division of Pollution Surveillance

1014 Broadway

Cincinnati, Ohio 45202

D. G. Ballinger

1 Federal Water Pollution Control Administration Physical and Engineering sciences Section

$T A \& I$

U. S. Dept. of the Interior Cincinnati, Ohio 45213

M. W. Lammering

1 French Atomic Energy Commission Cadarache Center of Nuclear Studies

Saint Paul Lez Durance

A. Brauby

1 Grant County Health Officer P. 0. Box 338 Ephrata, Washington 98823

J. P. Pflueger

2 The Johns Hopkins University Chesapeake Bay Institute

Baltimore, Maryland 21205

D. W. Pritchard

A. Okubo

1 Massachusetts Institute of

Technology Cambridge, Massachusetts

R. N. Crossett 
BNWL- 1341

No. of Copies

1 New York State Department of Health

Division of Environmental

Health Services

845 Central Avenue

Albany, New York 12206

W. J. Kelleher

1 Montana State Board of Health Division of Environmental Sanitation

Helena, Montana 59601

C. V. Brinck

2 Oregon State Board of Health 1400 S. W. 5th Avenue Portland, Oregon 97201

K. H. Spies

G. L. Toombs

1 Oregon State University Department of Oceanography Corvallis, Oregon 97331

W. O. Forster

1 Puerto Rico Nuclear Center Mayaguez, Puerto Rico 00708

F. G. Lowman

1 Radiofysiska Institute Lasarettet

Lund, Sweden

G. Svensson

$1 \quad$ Reed College

Department of Chemistry

Portland, Oregon 97202

A. F. Scott

1 Reynolds Electrical

and Engineering Co., Inc. AEC Contract Office

P. O. Box 1360

Las Vegas, Nevada 89101

Mildred Pearce

Technical Librarian

1 Science and Technology

Agency of Japan

Atomic Energy Bureau

$3-4$, Kasumigaseki, Chiyoda-Ku

Tokyo, Japan

Hiroshi Murata

4 Scriops Institute

of Oceanography

La Jolla, California 92037

T. R. Folsom

E. D. Golberg

J. D. Is a acs

M. B. Schaefer
No. of

Copies

1 Smithsonian Institute

Washington, D. C. 20560

M. G. Gross

2 Union Carbide Corp. (ORNL)

Oak Ridge, Tennessee 37830

E. D. Gupton

Health Physics Division

E. G. Struxness

1 United Kingdom Atomic Energy

Aurtmori ty

Chapelcross, England

J. H. Martin

1 United Kingdom Atomic Energy Authority

H. J. Dunster

$2 \quad$ U. S. Army Corps of Engineers North Pacific Division

210 Customhouse

Portland, Oregon 97208

J . B. Lockett

E. M. Mains

1 U. S. Fish and Wildlife Service Bureau of Commercial Fisheries Biological Laboratory Beaufort, North Carolina 28516

T. R. Rice

1 U. S. Fish and Wildlife Service Bureau of Commercial Fisheries 2725 Montlake Blvd.

Seattle, Washington 98102

D. L. Alverson

1 U. S. Geological Survey

345 Middlefield Road

Men1o Park, California 94025

P. C. Benedict

1 U. S. Geological Survey 830 N. E. Ho11aday

Portland, Oregon 97232

W. L. Haushild

1 U. S. Public Health Service 50 Fulton Street San Francisco, California 94102

1 U. S. Public Health Service Bureau of Radiological Health Washington, D. C. 20201

J. G. Terrill, Jr. 
No. of

Copies

1 U. S. Public Health Service

109 Holton Street

Winchester, Massachusetts 01890

Director, Northeastern

Radiological

Health Laboratory

2 U. S. Public Health Service

Bureau of Radiological Health

12720 Twinbrook Parkway

Rockville, Maryland 20852

Chief, Division

of Environmental Radiation

D. L. Snow

1 U. S. Public Health Service

Southwestern Radiological

Health Laboratory

Las Vegas, Nevada 89114

R. D. Tate

1 University of Minnesota 1108 Mayo Memorial Hospital Minneapolis, Minnesota 55455

C. P. Straub

1 University of California

Davis', California 95616

L. K. Bustad

2 University of Washington

Department of Oceanography

C. A. Barnes

Laboratory of Radiation Ecology

A. H. Seymour

1 Vanderbilt University

Department of Sanitary

and Water Resources Engineering

Nashville, Tennessee 37203

F. L. Parker

Wa11a Walla County-City-Health

Office

Walla Walla, Washington 99362

C. E. Sharp

Washington State Department

of Fisheries

Point Whitney

Brinnon, Washington 98320

C. E. Lindsay

1 Washington State Department

of Fisheries

Room 115; Gen. Adm. Blde.

Olympia, Washington 98501

D. E. Kauffman
No. of

Copies

1 Washington State Department

of Game

600 North Capital Way

Olympia, Washington 98501

R. C. Meigs

2 Washington State Department of Health

1510 Smith Tower

Seattle, Washington 98104

R. L. Stockman

P. W. Hildebrandt

3 Washington State Pollution

Control Commission

Olympia, Washington 98501

A. T. Neale

G. Hansen

A. Livingston

1 Washington State University

Department of Civil Engineering Pullman, Washington 99163

S. K. Bhagat

1 World Health Organization

Geneva, Switzerland

R. L. Dobson

1 Yakima County Health District

City Hall

Yakima, Washington 98901

Health Officer

ONSITE-HANFORD

1 AEC Chicago Patent Group

R. K. Sharp (Richland)

21 AEC Rich1and Operations Office

W. Devine, Jr.

0 . J. Elgert

D. R. Elle

J. E. Goodwin

W. E. Lotz

H. E. Parker

C. R. Qualheim

P. G. Rhoades

C. L. Robinson

R. B. St. John

M. W. Tiernan (10)

D. G. Williams

5 Atlantic Richfield Hanford Company, Inc.

G. E. Backman

D. J . Brown

B. J . McMurray

H. L. Maxfield

ARHCO File 
BNWL- 1341

No. of Copies

3

Battelle Memorial Institute

Benton-Franklin Health Center Pasco, Washington 99301

V. E. Michael

12

Douglas United Nuclear, Inc.

T. W. Ambrose

D. A. Baker

P. A. Carlson

C. D. Corbit (2)

V. V. Johnson

C. W. Kuhlman

W. S. Nechodom

D. W. Peacock

L. F. Reilly

O. C. Schroeder

DUN File

1 Hanford Environmental Health Foundation

F. E. Adley

1 ITT Federal Support Services, Inc.

R. H. Wilson

1 J.A. Jones Construction Co.

L. C. Roos

1 Kennewick Water Superintendent 220 W. Kennewick Avenue

Kennewick, Washington 99336

H. Ray

1 Pasco Water Superintendent

412 W. Clark Street

Pasco, Washington 99301

C. F. Whetsler

RDT Assistant Director

for Pacific Northwest Programs

Rich 1 and Water Superintendent 505 Swift Blvd.

Richland, Washington 99352

J . A. McCool

U. S. Testing Company, Inc.

D. B. Wilcox
No. cf

Copies

78

Battelle-Northwest

D. W. Alton

W. J. B air

C. A. Bennett

P. J. Blumer

R. J . Brouns

L. A. Carter

J. P. Corley

C. E. Cushing

G. M. Dalen

D. H. Denham

T. H. Essig

W. L. Fisher (20)

R. F. Foster (10)

R. B. Hall

K. R. Heid

W. C. Hanson

M. M. Hendrickson

J . F. Honstead

W. C. Horton

R. T. Jaske

J. J. Jech

R. L. Junkins

L. J . Kirby

H. A. Kornberg

H. V. Larson

R. E. Nakatani

J. M. Nielsen

T. P. O'Farrel1

H. M. Parker

R. W. Perkins

R. H. Scott

J. M. Selby

C. L. Simpson

J. K. Soldat

W. L. Templeton

C. J. Touhill

C. M. Unruh

B. E. Vaughan

E. E. Voiland

D. G. Watson

C. B. Wilson

N. G. Wittenbrock

F. W. Woodfield

Technical Publications (2)

Technical Information (5) 